\title{
ALANYA GELENEKSEL TOPHANE EVLERININ CEPHELERINDE MIMARI ELEMAN VE MALZEMENIN DÖNÜŞÜMÜ
}

\section{ALANYA ARCHITECTURAL ELEMENTS AND MATERIALS PERCEPTION AT THE FOUNDATIONS OF TRADITIONAL TOPHANE HOUSES}

\author{
Hicran Hanım Halaç*, İpek Demir**
}

Öz

Yapılan çalışmada, koruma amaçı yapılması gereken restorasyon eyleminin yapıların özgünlüğünü kaybettirecek biçimde uygulandığı tespit edilmiştir. Çalışma kapsamında Alanya geleneksel Tophane evlerinin cephelerindeki mimari eleman ve malzemenin özgünlük ve değişmişlik durumları incelenmiştir.

Yapılan çalışma; alan çalışmaları, kurum arşivleri ve literatür çalışmasıyla desteklenerek yürütülmüştür. Ulaşılabilen projeler, eski fotoğraflar ve çekilen yeni fotoğraflar üzerinden de değerlendirme yapılabilmiştir.

Tarihi yapılarda görülen hasar türleri ve nedenlerinden olan yanlış malzeme seçimiyle farklı detay çözümlerinin ortaya çıkardığı restorasyon sorunları, çalışma alanımızda araştııılmış, incelenmiş ve değerlendirilmiştir.

Çalışma sonucunda ise restorasyonun günümüzde özgün malzeme ve yerel işçilikten uzak, yapının özgün durumuna uyumsuz yapılıp, mevcut değerlerinden uzaklaştığı tespit edilmiştir. Bu şekilde gelecek kuşaklara doğru bilgi ve belge aktarılamamaktadır.

İgili kurumların kaynak paylaşımında bulunmaları halinde, sorunların hangi aşamada ortaya çıktığı tespit edilip, doğru müdahaleler de yapılabilir. Bu tespitlerle özelliğini henüz kaybetmemiş, kurtarılmayı bekleyen yapılar için mevcut durumun hızlıca belgelenip değişmeden onarılması, bölge kimliği açısından önemli bir adım olacaktır. Bu makale, Alanya Geleneksel Tophane Evlerinin cephelerinde yapılan müdahale kararı örnekleminde restorasyon çalışmalarında mimari eleman ve malzemenin dönüşümü üzerine öneriler içermektedir.

Anahtar Kelimeler: Alanya, Tophane Mahallesi, Müdahale Kararları, Malzeme.

\section{Abstract}

It has been observed that, protection purpose restoration is applied in such a way as to lose the originality of thestructures. In the study, the changing situation and the originality of the architectural elements and materials on Alanya traditional Tophane houses' facades were examined.

The study was supported by field studies, institutional archives and literature studies. Reached projects, old and new photographs also was evaluated.

Başvuru tarihi: 15.10.2017 - Kabul tarihi: 15.12.2017

*Doç. Dr., Anadolu Üniversitesi, Mimarlık ve Tasarım Fakültesi, Mimarlık Bölümü, hicranhalac@gmail.com.

*** Mimar, Anadolu Üniversitesi, Fen Bilimleri Enstitüsü, Mimarlık ABD, Mimari Koruma BD Yüksek Lisans, ipekdemir0@gmail.com. 


\section{SDÜ ART-E}

Güzel Sanatlar Fakültesi Sanat Dergisi

The restoration problems of different detail solutions with the choice of the wrong material from the types and causes of the damage seen in the historical buildings have been researched, examined and evaluated in our work area.

As a result, it is observed that nowadays, the restoration is away from the original material and local workmanship, is made in compatible with the original state of the structure and away from its present values. In this way, the right information and documents can't be transmitted to future generations. If the relevant institutions share resources, it is possible to determine the stage in which the problems have a risen and to make correct interventions. For these structures, have not yet lost their features and arewaitingto be rescued, the existing situation must documented quickly and repairing with out any changes will be an important step in theidentity of theregion. This study includes thes uggestion on transformation of architectural elements and materials in restoration works deciding in the sampling of the intervation on the facades of Alanya Tophane'sTraditional Houses.

Keywords: Alanya,Tophane Neighborhood, Intervention Decisions, Material.

\section{Giriş}

"Restorasyon, sadece bir yapıyı yıkılmasın diye ayakta tutmak demek değildir. Restorasyon, o yapıyı var eden ve hem şimdi hem de gelecekte başvurabileceğimiz tarihsel kanıtları, verileri bozmaksızın gelecek kuşaklara aktarmak demektir" (Tanyeli, 2005:1). Ne yazık ki günümüzde restorasyona bu çerçeveden bakılmadığı durumlar vardır. Bu durum yapıların farklı birer yeni yapıya dönüşmesine yol açmakta, amaç koruma iken yok etmeye dönüşmektedir. Bu bağlamda ülkemizde doğal ve kültürel varlıkları korumak büyük bir sorun haline gelmiştir. Bundan dolayı gelecek kuşaklara doğru bilgi ve belgeyi aktarabilmek adına günümüzde 'koruma' kavramı daha çok önem kazanmaktadır. Tarihi yapıların gelecek nesillere aktarılması yapılacak doğru malzeme seçimleri ve çalışmalar ile mümkündür.

Bu bağlamda Selçuklu, Bizans, Osmanlı gibi büyük devletlere ev sahipliği yapmış olan Antalya ili, Alanya ilçesi, Tophane mahallesinde bulunan Osmanlı dönemine ait sivil mimarlık örneklerinin restorasyon kaynaklı geçirmiş olduğu değişimler incelenmiştir. Bölgede yer alan yapıların gelecek nesillere korunarak aktarılmasından ziyade alanın turizm bölgesi olmasından dolayı pek çok yapı dekor olmaya başlamıştır. Bu çalışmada genel olarak Alanya Tophane Mahallesi Sivil Mimarlık örneklerinin restore edilmiş cephelerinde oluşan malzeme kullanımı ve yapım tekniği problemleri ve nedenlerini tespit edip değerlendirerek çözüm önerilerini sunmak amaçlanmıştır. 


\section{SDÜ ART-E}

Güzel Sanatlar Fakültesi Sanat Dergisi

Çalışma kapsamında Antalya ili, Alanya ilçesi, Tophane mahallesinde, Koruma ve Geliştirme İmar Planında belirtilen Kültür Varlığı Niteliğinde Sivil Mimarlık Örneği (KV= Kültür Varlığı Niteliğinde Sivil Mimarlık Örneği) statüsünde bulunan 61 yapı tespit edilmiştir. Alanya Belediyesi Koruma Uygulama ve Denetleme Bürosundan (KUDEB), bu yapılardan 56'sının envanter/tescil fişlerine ulaşılabilmiştir. Yapılan arazi çalışmasında 61 yapının 47'sine temas edilebilmiştir. Geri kalan 14 yapıya ise, kale gezi güzergâhının dışında kalması, bakımsız ve atıl kısımlar olmasından dolayı ulaşılamamıştır. Bu 14 yapının, 10 tanesinin Alanya belediyesi kent bilgi sistemine 2014 yılında yüklenmiş olan fotoğraflarına ulaşılabilmiştir (Tablo1).

Tablo 1. Çalışma alanında tespit edilen yapıların veri kaynakları

\begin{tabular}{|l|c|c|c|}
\hline & $\begin{array}{c}\text { Toplam Yapı } \\
\text { Sayısı }\end{array}$ & $\begin{array}{c}\text { Tescil Fişine Ulaşılan } \\
\text { Yapı Sayısı }\end{array}$ & $\begin{array}{c}\text { Tescil Fişine Ulaşılamayan } \\
\text { Yapı Sayısı }\end{array}$ \\
\hline Arazide Ulaşılan Yapı Sayısı & 47 Adet & 43 Adet & 4 Adet \\
\hline $\begin{array}{l}\text { Kent Bilgi Sisteminden } \\
\text { Ulaşılan Yapı Sayısı }\end{array}$ & 10 Adet & 10 Adet & 1 Adet \\
\hline Ulaşılamayan Yapı Sayısı & 4 Adet & 3 Adet & 5 Adet \\
\hline Toplam Yapı Sayısı & $\mathbf{6 1 ~ A d e t ~}$ & $\mathbf{5 6}$ Adet & \\
\hline
\end{tabular}

2017 yılında bu yapılardan 24 tanesinin restorasyonu tamamlanmış, 32 tanesine dokunulmamış ve 1 tanesi restorasyon aşamasındadır. Bölgedeki restorasyon çalışmaları incelendiği zaman son yıllarda artan restorasyon uygulamalarının yeterli nitelikte olmadığı tespit edilmiştir. Restorasyon uygulamaları sırasında birçok aşamada farklı sorunlar ile karşılaşılabilmektedir. Soruna çözüm üretebilmek için öncelikle sorunun kaynağını tespit etmek gerekmektedir. Değerlendirme aşamasında ise ilgili kurum ve kuruluşların yeterli bilgi ve belge paylaşımı yapmamasından dolayı sadece 24 yapıdan 14'ünün eski fotoğraflarına ulaşılabilmiştir. Eski fotoğraflarına ulaşılan 14 yapı üzerinden ana değerlendirme yapılmıştır. Ayrıca alanın durumunu tipolojik olarak tespit etmek amacıyla restorasyon geçirmemiş yapılar üzerinden de incelemeler yapılmıştır. Çalışma kapsamında; inceleme, tespit, literatür çalışması, alan çalışması, dokunulmamış ve restorasyon geçirmiş yapı karşılaştırması, restorasyon geçirmiş yapılarda ulaşılabilen projeler, eski fotoğraflar ve çekilen yeni fotoğraflar üzerinden karşılaştırma ve değerlendirme yöntemleri kullanılmıştır. Çalışma alanında problemlerin hangi aşamada gerçekleştiğini tespit edebilmek için yeterli bilgi ve belgeye ulaşılamadığından pek çok yapıda eski-yeni fotoğraflar ve kaynaklardan yararlanarak bir değerlendirme yapılmıştır. 


\section{SDÜ ART-E}

Güzel Sanatlar Fakültesi Sanat Dergisi

Çalışılan alanda yer alan yapılar, Şener'in (1984) dokuyu inceleyen kitabı, Hacıkura'nın (2000) Tophane bölgesinde yer alan geleneksel Alanya evinin restorasyon projesini içeren tezi, Alanya kale evlerini anlatan Kapancı'nın (2008) tezi, Ceylan'ın (1997) makalesi ve Türkmen'in (1996) bildirisi, Bilici'nin (2004; 2010) rant nedenli bölgede yaşanan koruma sorunlarına değinen bildirisi, Barışta'nın (1996a; 1996b) Alanya evlerinde görülen ağaç ve taş işleri üzerine incelemelerinin yer aldığı bildirileri, farklı bölgelerde yapılmış olan restorasyon uygulama sorunlarını konu alan tezler ve makaleler incelenerek bilgi sahibi olunmuş, yapılan çalışmalardan çıkan sonuçlar ortaya konulmuştur. Literatüre bakıldığında Alanya evlerinin genel özellikleri, bölgenin rant kaynaklı yaşadığı sorunları, taş ve ahşap işçiliğine değinen çalışmalar bulunmaktayken, restorasyon kaynaklı değişmeleri ve bozulmaları içeren bir çalışmaya ulaşılamamıştır. Bu nedenle çalışma özgün olup, literatürdeki boşluğa değinmektedir.

Tarihi yapılarda meydana gelen çeşitli hasar türleri vardır. Bunların bir kısmı, hatalı malzeme kullanımından ortaya çıkmıştır. Uygun malzemenin seçilememesi yapı ömrünün tükenmesinde hızlandırıcı bir etki oluşturmaktadır. Tarihi yapıların düzenli bakımları yapıımadığı durumlarda doğa etkisi çeşitli hasarları tetikler ve malzeme yorulur, yıpranır. İnsanlar çeşitli nedenlerle (terk etme, bakımsızlık, kasıtlı tahrip...) kültürel miraslarımızı yıpratmakta hatta tamamen yok olmalarına sebebiyet vermektedir (Çavuş, 2001:27). İnsanların sebep olduğu kötü kullanım, tarihi yapıların yıpranma sürelerini kısaltan önemli etkenlerdendir.

Restorasyonda söz konusu fiziksel müdahalelerin kültür varlığının niteliğine bakılmaksızın bilimsel verilere dayandırılması gerekmektedir. Ayrıca özgünlük kavramına ise sadece biçimsel olarak bakmak değil malzemenin özgünlüğünü birincil alarak bakmak daha doğru bir yaklaşımdır. Bu yaklaşım kültür varlığını sadece görsel bir vitrin olarak ele almayıp malzemenin özgünlüğünü birincil olduğunu savunmaktadır (Asatekin, 1995:68). Bu yaklaşım türleri koruma alanında yazılmış olan yasalar ve tüzüklerde de ayrıntılı olarak belirtilmiştir. “Icomos Ahşap Tarihi Yapıların Korunması İçin İlkeler"in $4 .{ }^{1}$ ve $7 .{ }^{2}$ maddelerinde özgünlüğün bir

\footnotetext{
1“Koruma ve yaşatmanın temel amacı kültür varlığının tarihi özgünlügünü ve bütünlüğünü korumaktır. Her müdahale uygun araştırma ve değerlendirmelere dayandırımalıdır. Sorunlar mevcut koşul ve gereksinimlere göre, yapının estetik ve tarihi değerlerine, tarihi yapının veya sitin fiziksel bütünlüğüne saygı göstererek çözümlenmelidir."

2 "Müdahalelerde tarihi yapı bir bütün olarak ele alınmalı, taşıyıcı ögeler, dolgu panoları, dış kaplama, çatı, kapı ve pencereler dahil olmak üzere tüm malzeme eşit ilgi görmelidir. Temel ilke mevcut malzemeyi olabildiğince yerinde
} 


\section{SDÜ ART-E}

Güzel Sanatlar Fakültesi Sanat Dergisi

bütün olarak özgününü koruyarak müdahalelerin yapılması gerekliliğine, "Icomos Geleneksel Mimari Miras Tüzüğü"nün 3. Maddesinde ${ }^{3}$ geleneksel yapım sisteminin önemine, "Mimari Mirasın Analizi, Korunması ve Strüktürel Restorasyonu İçin Illkeler"in 3.12. maddesinde ${ }^{4}$ izleri korumanın önemine, 3.14. maddesinde ${ }^{5}$ mimari ögeleri kaldırmaktan veya değiştirmekten kaçınılması gerekliliğine, "Uluslararası Kültürel Turizm Tüzüğü-Kültürel Miras Değeri Taşıyan Alanlarda Turizm Yönetimi” tüzüğünün 2. 4. maddesinde ${ }^{6}$ turizm değeri taşıyan bölgelerde özgünlüğünün korunması gerekliliğine, Venedik Tüzügünün 3. maddesinde ${ }^{7}$ kültür mirasının belge değeri taşıdığına değinilmektedir.

Bu nedenle restorasyonu yapılacak yapının günümüzdeki durumunun incelenmesiyle yapının geçirmiş olduğu değişimlerin bilinmesi ilk aşamadır. Yapının geçmişi, benzer yapılarla karşılaştırmalı analizi ile ortaya konulacak restitüsyon projesi, restorasyon projesinin özünü oluşturmaktadır (Asatekin, 1995:69).

Bu bakımdan restitüsyon sürecinde kültürel miraslarımıza ait geçmiş dönemlerdeki yapı malzemelerinin analizi, karakterizasyonu ve değerlendirilmesi bu yapıların restorasyonlarında kullanılacak yapı malzemelerinin doğru seçilmesi için oldukça önemlidir. Bu şekilde özgününe uygun malzemeler seçilerek yapılmış olan müdahaleye yapı daha hızlı uyum sağlar. Bu nedenle restorasyon sırasında seçilecek yapı malzemesi, özgününe uygun, yerel kaynaklardan yararlanılarak seçilmelidir (Pekmezci, 2012:139).

\section{Alanya Tophane Mahallesi Sivil Mimarlık Örnekleri}

Alanya Kale bölgesi, Hisariçi ve Tophane mahallesi olmak üzere, iki mahalleden oluşmaktadır. Ehmedek ve İçkale arasında kalan Hisariçi mahallesinde görülen evler bahçeli,

tutmaktır. Koruma sıva, boya, kaplama, duvar kağıdı gibi bitirme ayrıntılarını da kapsamalıdır. Eğer sıva vb. yüzeylerin yenilenmesi gerekirse, olabildiğince özgün malzemelere, yapım tekniklerine ve yüzey dokularına sadık kalınmalıdır."

3 "Geleneksel yapım sistemlerinin ve zanaatların sürdürülmesi geleneksel ifade için temel gereksinimdir ve bu yapıların onarım ve restorasyonları için gereklidir...."

4 “Her müdahale mümkün olduğunca, strüktürün ilk tasarımına, yapım tekniğine ve tarihi değerine saygı göstermeli ve onun gelecekte de anlaşılmasını sağlayacak izleri korumaya özen göstermelidir."

5“Herhangi bir tarihi malzeme veya belirgin mimari öğeyi kaldırmak veya değiştirmekten mümkün olduğunca kaçınılmalıdır."

6 “Kültür varlığı değeri taşıyan yerlerin ve koleksiyonların özgünlüğünün korunması önemlidir...”

7 "Anıtların korunmasında ve onarılmasındaki amaç, onları bir sanat eseri olduğu kadar, bir tarihi belge olarak da korumaktır." 
ahşap hatıllı, moloz taşlı genellikle iki katlı yapılardır. Yolun alt kısmında, yamaçta yer alan Tophane mahallesi ise eski Alanya kent dokusunun görülebildiği tek yerdir (Kapancı, 2008:42) (Görsel1).

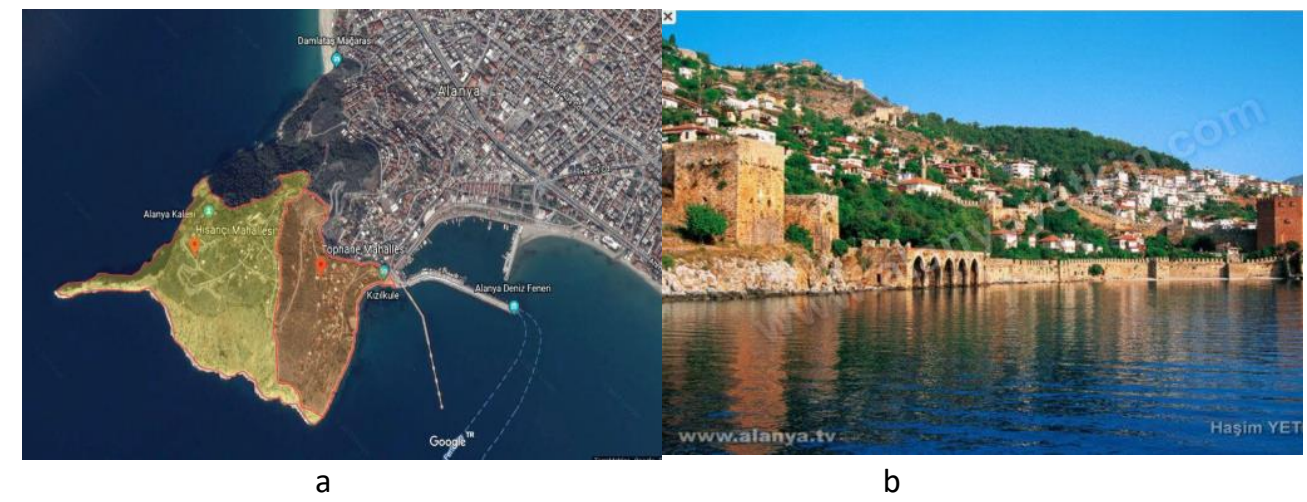

Görsel 1. a) Kale Bölgesi Tophane ve Hisariçi Mahalleleri. b) Tophane Mahallesi Silüeti.

Surlarla çevrili Tophane mahallesinde yer alan geleneksel konutlar Alanya'nın tarihsel mimari kimliğini göstermektedir. Bu yapılar alanın iklimsel, topografik ve malzeme özelliklerinin bir araya gelmesiyle oluşmuş yapılardır (Hacıkura, 2000:30).

Yapılarda uygulanan geleneksel yapım teknikleri, cephelerde rahatıkla gözlenebilmektedir. Zemin katlar moloz taş duvar; birinci katlarda manzaraya bakan cepheler, bağdadi; yamaca bakan cepheler ise moloz taş kullanılarak yapılmışlardır. Zemin katların, ahır veya depo olarak kullanılmasından dolayı, pencere sayısı az, küçük ve emniyet açısından, demir parmaklıdır. Bazı yapılarda ise pencere bulunmamaktadır.

En dikkat çekici cephe ise birinci katın manzaraya bakan kısmıdır. Bu bölüm, ahşap söveli, dört ayrı ahşap kapağı ve yöreye özgü demir parmaklıkları olan büyük pencereli kısımdır. Kimi yapılarda bu cephede yer alan pencerelerin üzerinde küçük boyutlu tepe pencereleri yer alır. Cephede süsleme yapı elemanlarıyla sağlanmıştır. Farklı tekniklerle yapılan pencere kapakları dikkat çekmektedir (Hacıkura, 2000:41) (Görsel 2). 


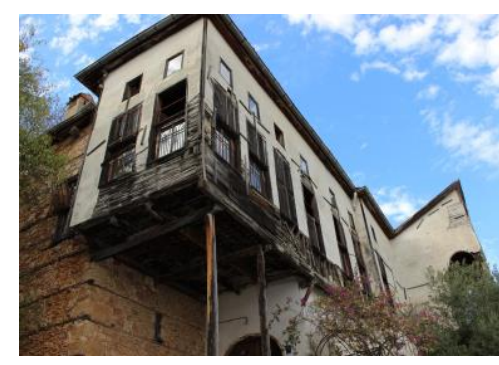

a

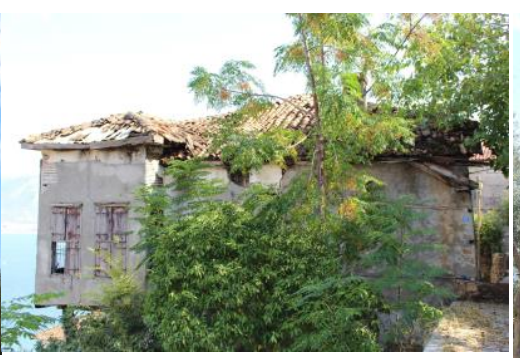

b

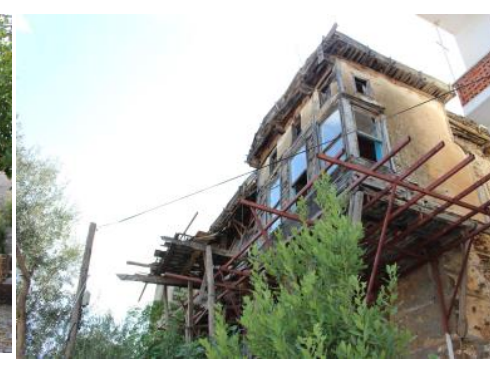

C

Görsel 2. a) Özgününü Büyük Oranda Korumuş Alanya Tophane Geleneksel Evi 15 Nolu Yapı.

b) Özgününü Büyük Oranda Korumuş Alanya Tophane Geleneksel Evi 31 Nolu Yapı.

c) Özgününü Büyük Oranda Korumuş Alanya Tophane Geleneksel Evi 33 Nolu Yapı.

İnceleme alanında, Koruma ve Geliştirme İmar Planında belirtilen KV statüsünde bulunan 61 yapı tespit edilmiştir. Bu 61 yapıdan 57'sinin bilgilerine ulaşılabilmiştir (Tablo 2).

Tablo 1. Tophane Mahallesinde Yer Alan Tescilli Sivil Mimarlık Örneği Yapılar 
SDÜ ART-E

Güzel Sanatlar Fakültesi Sanat Dergisi

Aralık'17 Cilt: 10 Sayı: 20

ISSN 1308-2698

\begin{tabular}{|c|c|c|c|c|c|c|c|c|c|c|c|c|c|c|c|c|}
\hline \multirow[b]{2}{*}{ 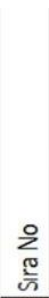 } & \multirow[b]{2}{*}{ 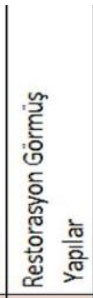 } & \multirow[b]{2}{*}{ 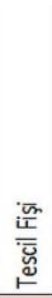 } & \multirow[b]{2}{*}{ 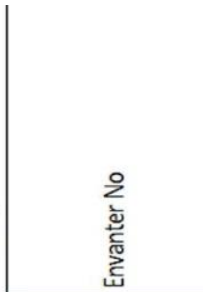 } & \multirow[b]{2}{*}{ 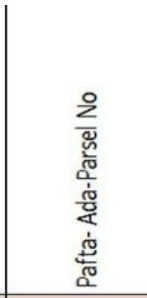 } & \multirow[b]{2}{*}{ 产 } & \multirow[b]{2}{*}{$\frac{\overrightarrow{\underline{d}}}{\underline{m}}$} & \multicolumn{2}{|c|}{ Foto } & \multicolumn{8}{|c|}{ Projeler-Raporlar } \\
\hline & & & & & & & 总 & 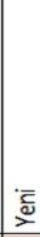 & & 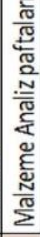 & 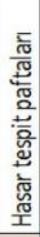 & 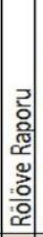 & 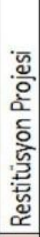 & 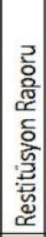 & 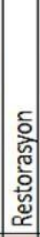 & 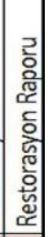 \\
\hline 1 & $\checkmark$ & 1 & $07.02 / 1.3 / 115$ & $45-291-1$ & Tophane mh. No: 4 & $\begin{array}{l}\text { Alan Yönetim } \\
\text { Ofisi }\end{array}$ & & 1 & & & & & & & & \\
\hline 2 & $\checkmark$ & 1 & $07.02 / 1.3 / 117$ & $45-419-2$ & Tophane mh. No:3, 5 & Konut & 1 & 1 & & & & & & & & \\
\hline 3 & & 1 & $07.02 / 1.3 / 113$ & $45-292--1$ & Tophane mh. No:7 & Konut & & 1 & & & & & & & & \\
\hline 4 & & 1 & & $45-418-1$ & Tophane mh. No: 6 & & & 1 & & & & & & & & \\
\hline 5 & $\checkmark$ & 1 & $07.02 / 1.3 / 71$ & $43-289-11$ & Tophane mh. No: 3 & Konut & & 1 & & & & & & & & \\
\hline 6 & & 1 & $07.02 / 1.3 / 70$ & $43-289-6$ & Tophane mh. No: 1 & Kullanılmıyor & & 1 & & & & & & & & \\
\hline 7 & $\checkmark$ & 1 & $07.02 / 1.3 / 74$ & $43-294-22$ & Tophane mh. No: 6 & Cafe & & 1 & & & & & & & & \\
\hline 8 & & 1 & $07.02 / 1.3 / 73$ & $43-294-23$ & Tophane mh. No:4 & Kullanılmıyor & & 1 & & & & & & & & \\
\hline 9 & $\checkmark$ & 1 & & $403-1,2$ & Tophane $\mathrm{mh}$. & Konut & 1 & 1 & 1 & & & 1 & & 1 & & 1 \\
\hline 10 & $\checkmark$ & 1 & $07.02 / 1.3 / 76$ & $45-403-2$ & Tophane mh. No: 3 & Konut & 1 & 1 & 1 & 1 & 1 & 1 & & 1 & & 1 \\
\hline 11 & $\checkmark$ & 1 & & 44-401-1 & Tophane mh. No:24 & Butik Otel & 1 & 1 & & & & & & & & \\
\hline 12 & $\checkmark$ & 1 & $07.02 / 1.3 / 77$ & $45-403-4$ & Tophane mh. No: 1 & Konut & 1 & 1 & & & & & & & & \\
\hline 13 & $\checkmark$ & 1 & $07.02 / 1.3 / 89$ & $44-409-2$ & Tophane mh. No: 1 & Konut & 1 & 1 & & & & & & & & \\
\hline 14 & & 1 & & $409-3$ & Tophane mh. & KullanıImıyor & & 1 & & & & & & & & \\
\hline 15 & & 1 & $07 / 02 / 1.3 / 48$ & $286-11$ & & & & 1 & & & & & & & & \\
\hline 16 & $\checkmark$ & 1 & $07.02 / 1.3 / 91$ & $45-293-4$ & Tophane mh. No:9 & & & 1 & & & & & & & & \\
\hline 17 & $\checkmark$ & 1 & $07.02 / 1.3 / 94$ & $45-410-1$ & Tophane mh. No: 13 & Konut & & 1 & & & & & & & & \\
\hline 18 & $\checkmark$ & 1 & & $409-9$ & Tophane $\mathrm{mh}$. & Konut & 1 & 1 & & & & & & & & \\
\hline 19 & & 1 & $07.02 / 1.3 / 95$ & $44-409-18$ & Tophane mh. No:20 & Konut & & 1 & & & & & & & & \\
\hline 20 & & & & $411 / 13$ & & Harabe & & 1 & & & & & & & & \\
\hline 21 & & 1 & & $400-2$ & Tophane $\mathrm{mh}$. & Harabe & & 1 & & & & & & & & \\
\hline 22 & & 1 & & $400-6$ & Tophane mh. & Kullanilmıyor & & 1 & & & & & & & & \\
\hline 23 & & 1 & $07.02 / 1.3 / 101$ & $44-414-5$ & Tophane mh. No:68 & Kullanilmıyor & & 1 & & & & & & & & \\
\hline 24 & & 1 & $07.02 / 1.3 / 102$ & $44-414-6$ & Tophane mh. No:70 & Konut & & 1 & & & & & & & & \\
\hline 25 & $\checkmark$ & 1 & $07.02 / 1.3 / 85$ & $44-401-9$ & Tophane mh. No:36 & Konut & 1 & 1 & & & & & & & & \\
\hline 26 & $\checkmark$ & & & $402-1$ & Tophane mh. & Konut & 1 & 1 & & & & & & & & \\
\hline 27 & & 1 & $07.02 / 1.3 / 84$ & $44-401-7$ & Tophane mh. No:28 & Konut & & 1 & & & & & & & & \\
\hline 28 & & 1 & $07.02 / 1.3 / 85$ & $44-401-8$ & Tophane mh. No:32 & Konut & & 1 & & & & & & & & \\
\hline 29 & & 1 & $07.02 / 1.3 / 78$ & $43-294-11$ & Tophane mh. No:18 & Konut & & 1 & & & & & & & & \\
\hline 30 & & 1 & $07.02 / 1.3 / 75$ & $43-294-9$ & Tophane mh. No:16 & Kullanilmıyor & & 1 & & & & & & & & \\
\hline 31 & & 1 & $07.02 / 1.3 / 80$ & $43-294-14$ & Tophane mh. No:38 & Projesi Çiziliyor & & 1 & & & & & & & & \\
\hline
\end{tabular}




\begin{tabular}{|c|c|c|c|c|c|c|c|c|c|c|c|c|c|c|c|}
\hline 32 & & 1 & $07.02 / 1.3 / 81$ & $44-413-2$ & Tophane mh. No:39 & Konut & & 1 & & & & & & & \\
\hline 33 & & 1 & $07.02 / 1.3 / 51$ & $44-287-6,7$ & Tophane mh. No:43 & Kullanılmıyor? & & 1 & & & & & & & \\
\hline 34 & $\checkmark$ & & & $294-28$ & Tophane mh. & Konut & & 1 & & & & & & & \\
\hline 35 & $\checkmark$ & 1 & $07.02 / 1.3 / 54$ & $43-407-4$ & Tophane mh. & Konut & 1 & 1 & & & & & & & \\
\hline 36 & & 1 & $07.02 / 1.3 / 56$ & $43-286-3,5$ & Tophane mh. No:13 & Konut & 1 & 1 & & & & & & & \\
\hline 37 & $\checkmark$ & 1 & $07.02 / 1.3 / 63$ & $43-283-26$ & Tophane mh. No:12 & Konut & 1 & 1 & & & & & & & \\
\hline 38 & $\checkmark$ & 1 & $07.02 / 1.3 / 64$ & $43-283-24$ & Tophane mh. No:22 & Konut & & 1 & & & & & & & \\
\hline 39 & & 1 & $07.02 / 1.3 / 72$ & $43-408-1$ & Tophane mh. No:5 & & & 1 & & & & & & & \\
\hline 40 & $\checkmark$ & 1 & $07.02 / 1.3 / 65$ & $43-283-11$ & Tophane mh. No: 6 & Konut & & 1 & & & & & & & \\
\hline 41 & $\checkmark$ & 1 & $07.02 / 1.3 / 46$ & $44-295-3$ & Tophane mh. No: 25 & Konut & 1 & 1 & 1 & & 1 & 1 & 1 & 1 & 1 \\
\hline 42 & & 1 & $07.02 / 1.3 / 58$ & $43-283-27$ & Tophane mh. No:10 & Kullanılmıyor & 1 & 1 & & & & & & & \\
\hline 43 & & 1 & $07.02 / 1.3 / 44$ & $43-285-8$ & Tophane mh. No:26 & Konut & & 1 & & & & & & & \\
\hline 44 & $\checkmark$ & 1 & $07.02 / 1.3 / 34$ & $46-300-24$ & Tophane mh. No:26 & Vakıf Binası & & 1 & & & & & & & \\
\hline 45 & & 1 & $07.02 / 1.3 / 39$ & $46-299-1$ & Tophane mh. No:51 & Konut & & 1 & & & & & & & \\
\hline 46 & $\checkmark$ & 1 & $07.02 / 1.3 / 37$ & $43-284-7$ & Tophane mh. No: 41 & Konut & 1 & 1 & & & & & & & \\
\hline 47 & & & & $284-4$ & Tophane mh. & Konut & & 1 & & & & & & & \\
\hline 48 & $\checkmark$ & 1 & & $284-2,8$ & Tophane mh. & Konut & 1 & 1 & & & & & & & \\
\hline 49 & & 1 & $07.02 / 01.3 / 35$ & $46-300-10$ & Tophane mh. No:24 & Konut & \multirow{8}{*}{\multicolumn{9}{|c|}{$\begin{array}{l}\text { Alanya Belediyesi Kent Bilgi } \\
\text { Sisteminden elde edilen } \\
2014 \text { görselleri } \\
\text { http://kbs.alanya.bel.tr/\# } \\
\text { (erişim tarihi : 04.01.2017) }\end{array}$}} \\
\hline 50 & & 1 & & $44-295-22$ & Tophane mh. No:28 & Kullanılmıyor & & & & & & & & & \\
\hline 51 & & 1 & $07.02 / 1.3 / 96$ & $44-413-8$ & Tophane mh. No:52 & Konut & & & & & & & & & \\
\hline 52 & $\checkmark$ & 1 & $07.02 / 1.3 / 97$ & $44-413-9$ & Tophane mh. No:54 & Konut & & & & & & & & & \\
\hline 53 & & 1 & $07.02 / 1.3 / 98$ & 44-414-8 & Tophane mh. No:58 & Konut & & & & & & & & & \\
\hline 54 & & 1 & & $44-417-17$ & Tophane mh. No:72 & Konut & & & & & & & & & \\
\hline 55 & & 1 & $07.02 / 1.3 / 108$ & $44-415-2$ & Tophane mh. No:84 & Kullanılmıyor & & & & & & & & & \\
\hline 56 & & 1 & & $44-412-4$ & Tophane mh. No:98 & Konut & & & & & & & & & \\
\hline 57 & & 1 & $07.02 / 1.3 / 111$ & 44-297-2 & Tophane mh. No:19 & Kullanılmıyor & & & & & & & & & \\
\hline
\end{tabular}

\section{Alanya Tophane Mahallesi Restorasyon Görmüş 14 Yapının Cephe Değişimlerinin Değerlendirilmesine İlişkin Bulgular}

Çalışma Kapsamında Alanya ilçesi Tophane mahallesinde yer alan 19. yüzyıl sonu ve 20. yüzyıl başına tarihlenmekte olan sivil mimarlık örneği yapıların cephe özelliklerinin korunma durumu incelenmiştir. Bölgede yer alan 61 yapıdan bilgisine ulaşılabilen 57 yapının 24 tanesi restorasyon geçirmiş, 32 tanesi basit onarım dışında müdahale görmemiş, özgününü korumakta, 1 tanesi ise restorasyon aşamasındadır (bkz. Tablo 3). Eski fotoğraflarına ulaşabildiğimiz restorasyon geçirmiş yapı ise sadece 14 adettir. Yapılan değerlendirme eski-yeni fotoğraflarına ulaşılabilmiş bu 14 yapı üzerinden yapılmıştır. 
Tablo 2. Incelenen Yapıların Mevcut Durum Değerlendirmesi

\begin{tabular}{|c|c|c|c|}
\hline \multicolumn{2}{|c|}{ Restorasyon Geçirmiş Yapı Sayısı } & \multirow{2}{*}{$\begin{array}{c}\text { Dokunulmamış } \\
\text { Yapı Sayısı }\end{array}$} & $\begin{array}{c}\text { Uygulama Aşamasında } \\
\text { Olan Yapı Sayısı }\end{array}$ \\
\hline $\begin{array}{c}\text { Verilerine Ulaşılabilen } \\
\text { Yapı Sayısı }\end{array}$ & $\begin{array}{c}\text { Verilerine Ulaşılamayan } \\
\text { Yapı Sayısı }\end{array}$ & 32 & 1 \\
\hline 14 & 10 & 32 & 1 \\
\hline
\end{tabular}

Ulaşılabilen yapıların eski fotoğrafları ile karşılaştırma yapıldığında, yapıların büyük oranda değişikliğe uğradığı tespit edilmiştir. Bu değişiklikleri tespit ederken malzemenin mevcut halini koruması, eklenmesi, kaldırılması, değişiklikler (şekil değiştirme, boyut değiştirme, detay değiştirme, malzeme değiştirme) başlıkları altında inceleme yapılmıştır.

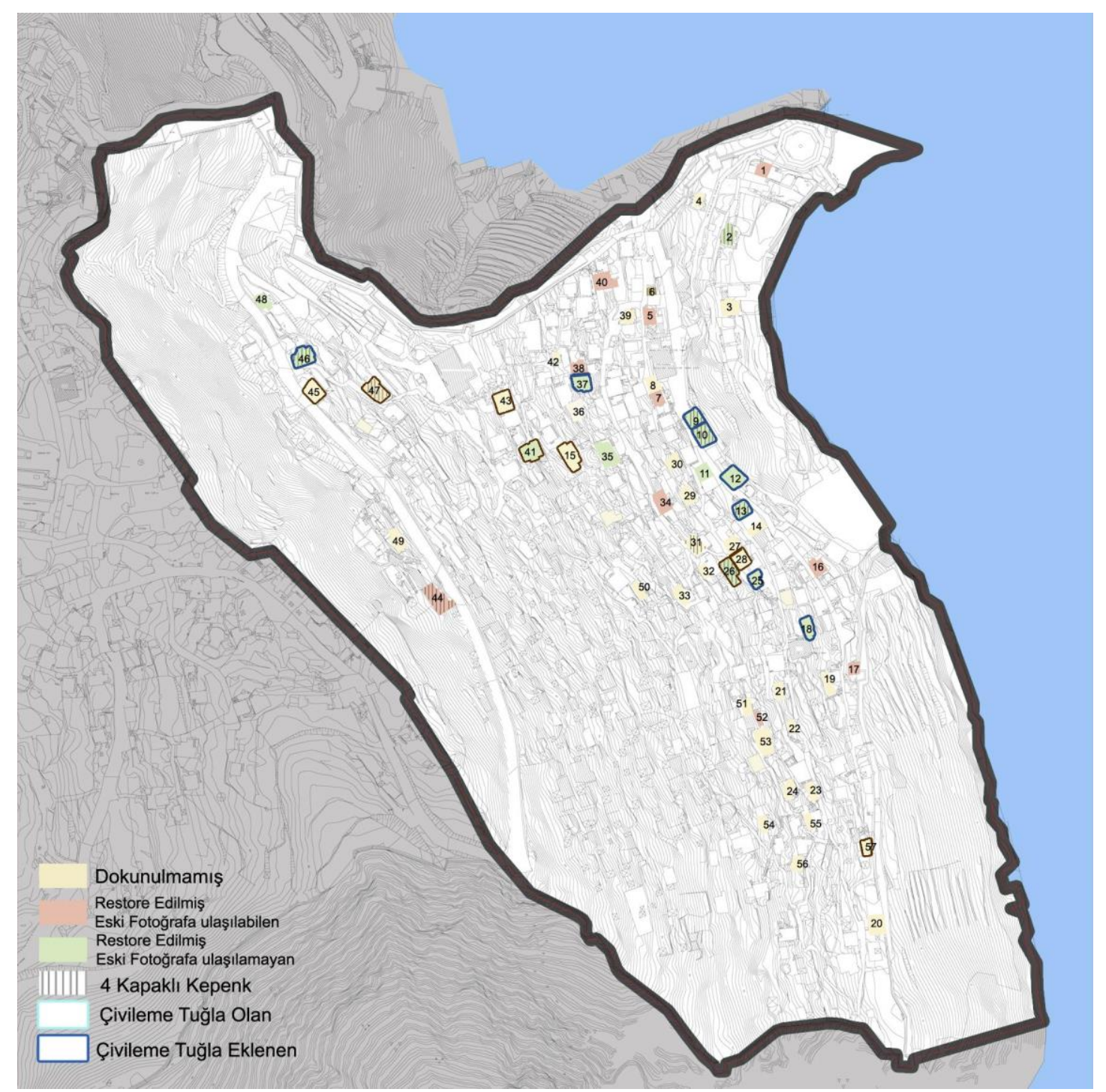

Görsel 3. Mimari Yapım Elemanlarında Tespit Edilen Değişimler. 
Incelemede; taş duvar örgüsü, harç sıva, merdiven, ahşap yapı elemanları taşıyıcı elemanlar, kaplama elemanları, doğrama elemanları başlıkları altında toplanmıştır. Alanda yapım elemanlarında tespit edilen değişimler Görsel 3 de gösterilmiştir.

\subsection{Taş Duvar Örgüsü}

En eski yapı malzemelerinden olan taş, hemen hemen her yerde ve her arazi koşulunda kolaylıkla bulunabilen tarihi yapılarda yaygın olarak kullanılan bir malzemedir. Tarihi yapıda birçok farklı noktada kullanılan taş, farklı fiziksel özelliklerine göre uygun yer ve göreve seçilmektedir (Küçükkaya, 2004:X).

Çalışma alanındaki yapıların temel ve zemin beden duvarları, belirli aralıklarda ahşap hatıllar atılarak örülmüş moloz taş duvarlardır. Serbest keski hareketleriyle yontulmuş moloz taşların çevresi, cephede, gelişigüzel şekilde yerleştirilmiş tuğla ve kiremit kırıklarıyla doldurulmuştur. Yöre halkı arasında çivileme denilen bu tekniğin bölgede geçmiş dönemlerden beri kullanıldığı bilinmektedir (Ceylan, 1997:79) Henüz restorasyon işlemi görmemiş yapılar üzerinde detaylı inceleme yapıldığı zaman çivileme tekniğinin genel durumu tespit edilmektedir (bkz. Tablo 4).

Tablo 3. Restore Edilmemiş Yapılarda Taş Duvarların Durum Tespiti

\begin{tabular}{|c|c|c|c|c|c|c|c|c|c|c|}
\hline Yap1 & 3 & 4 & 6 & 14 & 15 & 20 & 21 & 22 & 23 & 24 \\
\hline Fotoğraf & & & & & & & & & 6 & 8 \\
\hline Yap1 & $27-28$ & 29 & 30 & 31 & 32 & 33 & 43 & 45 & 47 & 50 \\
\hline Fotoğraf & & 45 & & & 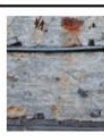 & 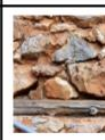 & & & (3) & $\frac{1}{2}$ \\
\hline
\end{tabular}

Tablo 5'de görüldüğü gibi alanda yapılan araştırma ve tespitlerden sonra incelenen 14 yapının $\% 78,57$ 'sinde(2, 9, 10, 11, 12, 13, 18, 25, 37, 46, 48 nolu yapılar) kullanılan taş çeşidi, boyutu değişmiştir, çivileme tekniği olağanın dışında dekor elemanı olarak kullanılmaya başlanmıştır. Tablo 4'de de görüldüğü gibi çivileme tuğla alanda sonradan eklenen bir süsleme elemanına dönüşmüştür. 
Tablo 4. Çivileme tuğlanın alandaki kullanım durumu

\begin{tabular}{|c|c|c|c|c|}
\hline \multirow{2}{*}{} & \multicolumn{2}{|l|}{ Eski-Yeni Halinde Bulunan } & \multicolumn{2}{c|}{ Sadece Yeni Halinde Bulunan } \\
\cline { 2 - 5 } & Yapı No & Yapı Sayısı & Yapı No & Yapı Sayısı \\
\hline Fotoğrafına Ulaşılabilen Yapılar & $26-41$ & 2 & $\begin{array}{c}9-10-11-12-13 \\
18-25-37-46-48\end{array}$ & 10 \\
\hline & \multicolumn{3}{|c|}{ Yapı No } & \multicolumn{2}{|c|}{ Yapı Sayısı } \\
\hline Dokunulmamış Yapılar & \multicolumn{2}{|c|}{$15-28-43-45-47$} & \multicolumn{2}{|c|}{5} \\
\hline
\end{tabular}

Eski fotoğraflarında geçmişinde çivileme uygulaması görülmeyen yapılarda da kullanılmaya başlandığı tespit edilmiştir. İncelenen 14 yapının \%14,28'inin(2yapı)eski halinde de uygulama görülürken 14 yapının \%71,42'sinde(9, 10, 11, 12, 13, 18, 25, 37, 46, 48 nolu yapılar) daha bu uygulamanın yapıldığı görülmektedir. 14 yapının \%7,14'ünde ( 2 nolu yapı) var olan çivileme tuğlanın kaldırıldığı, 14 yapının \%7,14'ünde ( 41 nolu yapı) ise aynı bırakıldığı, farklı bir müdahale yapılmadığı görülmektedir (Tablo 6). Tablo 4'de yer alan değişimlere baktığımız zaman çivileme tekniğinde gelişi güzel yerleştirilmesi gereken tuğla ve kiremitlerin düzenli, sistematik bir şekilde yapıldığı görülmektedir. Ayrıca bölgede özgününde olmamasına rağmen restorasyon uygulamasında çivileme tekniğinin kullanılmasının; yanlış bilginin aktarılmasına neden olup, bölgede var olan taş işçiliği tipolojisinde değişime neden olacağı varsayılmaktadır.

Tablo 5. Restore Edilmiş Yapılarda Taş Duvarların Durum Tespiti

\begin{tabular}{|c|c|c|c|c|c|c|c|}
\hline & Yap1 & 2 & 9 & 10 & 11 & 12 & 13 \\
\hline 2 & $\begin{array}{c}\text { Eski } \\
\text { Durum }\end{array}$ & int & & are & & is & \\
\hline త) & $\begin{array}{l}\text { Yeni } \\
\text { Durum }\end{array}$ & & & & & $\frac{5}{10}$ & 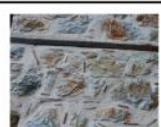 \\
\hline & Yap1 & 18 & 25 & 26 & 37 & 41 & 46 \\
\hline อ & $\begin{array}{c}\text { Eski } \\
\text { Durum }\end{array}$ & & $\frac{7 x+4}{3 x}$ & & & & \\
\hline ङ & $\begin{array}{l}\text { Yeni } \\
\text { Durum }\end{array}$ & 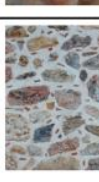 & $\frac{1}{10}$ & 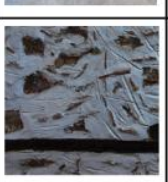 & $\begin{array}{l}x^{2}-1 \\
1 .\end{array}$ & 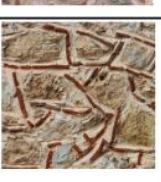 & 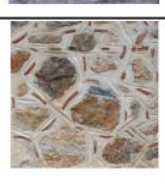 \\
\hline
\end{tabular}




\section{SDÜ ART-E}

Güzel Sanatlar Fakültesi Sanat Dergisi

Aralık'17 Cilt: 10 Sayı: 20

ISSN 1308-2698

\subsection{Harç-Sıva}

Eski Yunan ve Roma dönemlerinde kireçle oluşturulan sıva ve harçlar, çimento bulunana kadar yapı inşasında kullanılmıştır (Böke vd., 2004:90).

Alanda genel olarak bağlayıcı iki tip malzeme kullanılmaktadır. Bunlar; kireç-kum, toprak ve su karışımından oluşan çamur harcıdır. Sıva olarak da saman-kum-kireç karışımı kullanılmaktadır.

Bölgede yer alan yapıların duvar örgülerine bakıldığında farklı renk ve cins harç uygulamaları görünmektedir. İncelenen 14 yapının \%71,42'sinde(2-9-11-12-26-35-37-41-46-48 nolu yapılar) harç malzemesi değişmişken, 14 yapının \%28,57'sinde (10-11-18-25 nolu yapılar) harç eklemeleri tespit edilmiştir.

Harç ve sıva seçimi yapılırken yapı elemanlarını oluşturan taşların özellikleriyle benzer özellikte malzeme seçilmelidir (Zakar, 2013:85). Bu noktada harç malzemesinin değişmesi farklı bir dönemde yapılan bir müdahale olduğunu göstermesi adına doğru bir yaklaşım olabileceği düşünülmektedir. Fakat farklı özellikte bir malzeme kullanılması yapı malzemesi olan taşla ilişkisini azaltmanın yanında var olan belgeyi korunabilecek durumdayken yok edip yenilenmesi nedeniyle bilgi-belgeyi yok eden bir yaklaşıma dönüştüğü tespit edilmiştir.

\subsection{Merdivenler}

Kimi evlerde evin giriş kısmına arazideki dik konumundan ötürü dış cepheden bir merdiven yardımıyla ulaşılabilmektedir.

İncelediğimiz 14 yapının \%50’sine (7 yapı) dış cepheden merdivenle ulaşılırken, \%50'sine(7 yapı) ise direk yol kotundan ulaşılmaktadır. Bu 7 yapının \%14,28'ine(41 nolu yapı) merdiven eklendiği, 7 yapının \%14,28'inde de (46 nolu yapı) merdiven kaldırıldığı tespit edilmiştir. 7 yapının \%71,42'sinin (2-18-25-26-48 nolu yapı) merdiveninde ise şekil, boyut, malzeme gibi çeşitli değişiklikler tespit edilmiştir.

Yapıya merdiven eklenmesi, kaldırılması veya şekil, boyut ve malzeme değişimi, yeni yaşam şartlarının veya konfor şartlarının gerektirdiği dönüşümler olsa dahi özgününe bağlı kalarak mevcut haliyle çözümler üretilmesi yapının aslının kaybetmemesi anlamında son derece kıymetli uygulama altlıklarındandır. 


\section{SDÜ ART-E}

Güzel Sanatlar Fakültesi Sanat Dergisi

Aralık'17 Cilt: 10 Sayı: 20

ISSN 1308-2698

\subsection{Ahşap Yapı Elemanları}

Ahşap, işlenmesi ve taşınması kolay bir malzemedir. Hafif, çekme, basınç ve eğilmeye karşı dayanımı olduğundan büyük açıklıklarda ahşapla rahatça geçilebilmektedir (Mahrabel, 2006:22).

Bölgede ahşap malzemenin kiriş, hatıl, bağdadi çıtası, tavan, kapı, pencere ve dolapların yapımında kullanıldığı görülmektedir. Yapıda kullanılan ahşap çeşitleri katran, karaçam ve kızılçamdır. Katran dış kısımlarda, taş duvar arasındaki hatıllarda, ince kesilmiş bağdadi çıtalarında, çam ise evlerin iç kısmında kullanılmıştır (Barışta, 1996:393).

Çalışmada ahşap yapı elemanları Görsel 4'de gösterildiği gibi üç başlık altında incelenmiştir.

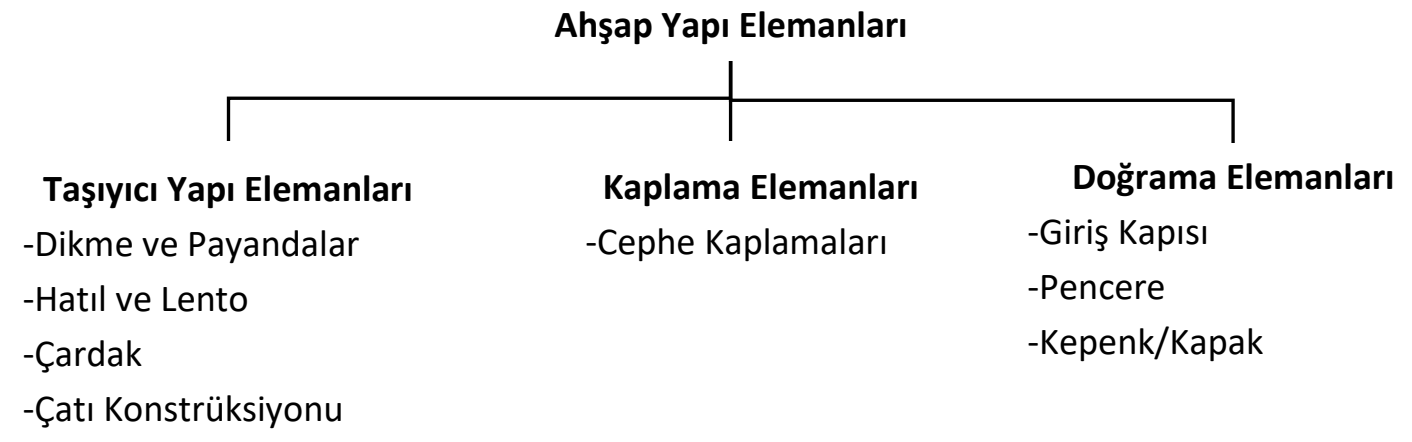

Görsel 4. Ahşap yapı elemanlarının incelenme şekli.

\subsubsection{Taşıyıcı Ahşap Yapı Elemanları}

- $\quad$ Dikme-Payanda

Bölgede yer alan dikmeler ve payandalar, ön cephede yer alan çıkmaları ve çardakları taşıyan genellikle kare kesitli ahşap elemanlardır.

İncelenen 14 yapının \%57,14'inde(8 yapı) dikme bulunurken, 14 yapının \%85,71'inde(12 yapı) payanda bulunmaktadır. Incelenen yapılardan dikme bulunan 8 yapının \%50'sine $(9,10$, 25, 26 nolu yapılar) dikme eklenirken, \%12,5'inde ( 2 nolu yapı) dikme aynı şekilde korunmuş, $\% 25^{\prime}$ inde (18 ve 48 nolu yapılar) kaldırılmış ve \%12,5'inde de (13 nolu yapı) detay değişimi görülmektedir. İncelenen yapılardan payanda bulunan 12 yapının \%58,33'üne $(9,11,13,18,26$, 37, 41 nolu yapılar) payanda eklenirken, \%16,66'sında (10 ve 46 nolu yapılar) aynı şekilde 


\section{SDÜ ART-E}

Güzel Sanatlar Fakültesi Sanat Dergisi

korunmuş, \%16,66'sında ( 2 ve 48 nolu yapılar) kaldırılmış ve \%16,66'sında da (18 ve 35 nolu yapılar) değişikliğe uğramıştır. Değişikliğe uğrayan yapılardan 1'i (18 nolu yapı) Şekil, 1'de (35 nolu yapı) boyut değiştirmiştir.

Strüktürel bir gereksinim olmadığı taktirde süsleme amaçlı yeni payanda ve dikmelerin eklenmesi veya değiştirilmesi, sayısının azaltılması mevcut bilgi-belgenin değişimine neden olmakta ve Alanya Tophane bölgesi geleneksel konut tipolojisini bozmaktadır. Bu davranışlar tarihi yapıyı 'popüler' yapma gayreti olarak algılanabilir ve yanıltıcı bir süreci doğurabilir.

\section{- Hatıl-Lento}

Hatıllar, yapılarda yatay yüklere dayanıklılı̆ı arttırmak ve yükleri yaymak için duvarlarda kurgulanan yatay bağlantı elemanlarıdır. Subasman seviyesinde, duvar bitiminde pencere alt üst hizalarında yer alırlar. Bölgede her yapıda farklılık gösterebilen birleşim detayları bulunmaktadır. Lentolar ise kapı pencere gibi açıklıkların üzerinden tekrar duvar örgüsünün devam etmesine olanak sağlayan yapı elemanlarıdır.

Incelenen 14 yapının \%92,85'inde(13 yapı) hatıl ve lento değerlendirilmesi yapılabilmiştir. 13 yapının \%30,76'sında (2, 26, 35, 41 nolu yapılar) aynen korunurken, $\% 15,38$ 'inde (9 ve 10 nolu yapılar) kaldırılan lento ve hatıllar tespit edilmiştir, \%23,07'sinde de (11, 18 ve 37 nolu yapılar) lento ve hatıl eklemeleri tespit edilmiştir. 13 yapının \%23,07'sinde (12, 13 ve 25 nolu yapılar) detay değişimi, \%7,69'unda da (46 nolu yapı) boyut değişikliği tespit edilmiştir.

Bu ekleme, kaldırma ve değişimlerin nedenleri büyük oranda günümüz konfor şartları nedeniyle açılan veya kapatılan pencere ve kapılardır. Strüktürel nedeniyle yapılan bu müdahalelerin uygun malzeme ve metod ile yapılması oldukça önemlidir.

\section{- $\quad$ Çardak}

Alanda en problemli görünen noktalardan biri halk arasında 'çardak' diye bilinen manzara yönündeki açık çıkmalardır. İncelenen 14 yapının \%85,71'inin(12 yapı) çardağına ulaşılabilmiştir. Arazinin eğimli olması, sık ağaçlıklı alanların olması bazı yapıların denize bakan cephelerine ulaşmamıza engel olmuştur. Bu nedenle 12 ve 37nolu yapının çardağıyla ilgili 
bilgiye ulaşılamamıştır. Eski fotoğraflarında izi çok net okunmayan hatta görülmeyen incelenen 12 yapının \%41,66'sına $(11,13,18,37$ ve 46 nolu yapılar) çardak eklenmiştir. Incelenen 12 yapının \%41,66'sında $(2,9,10,25$, ve 41 nolu yapılar) şekil, boyut ve malzeme değişimi tespit edilmiştir.

Bu çıkmaların üst örtüleri ile ilgili net bilgiye ulaşılamamıştır. Eski fotoğraflarında olmamasına rağmen bazı çardaklara da çeşitli tarzlarda üst örtü kurgulandığı tespit edilmiştir (Tablo 7, 8).

Tablo 6. Restore Edilmiş Yapılarda Çardak Durum Tespiti

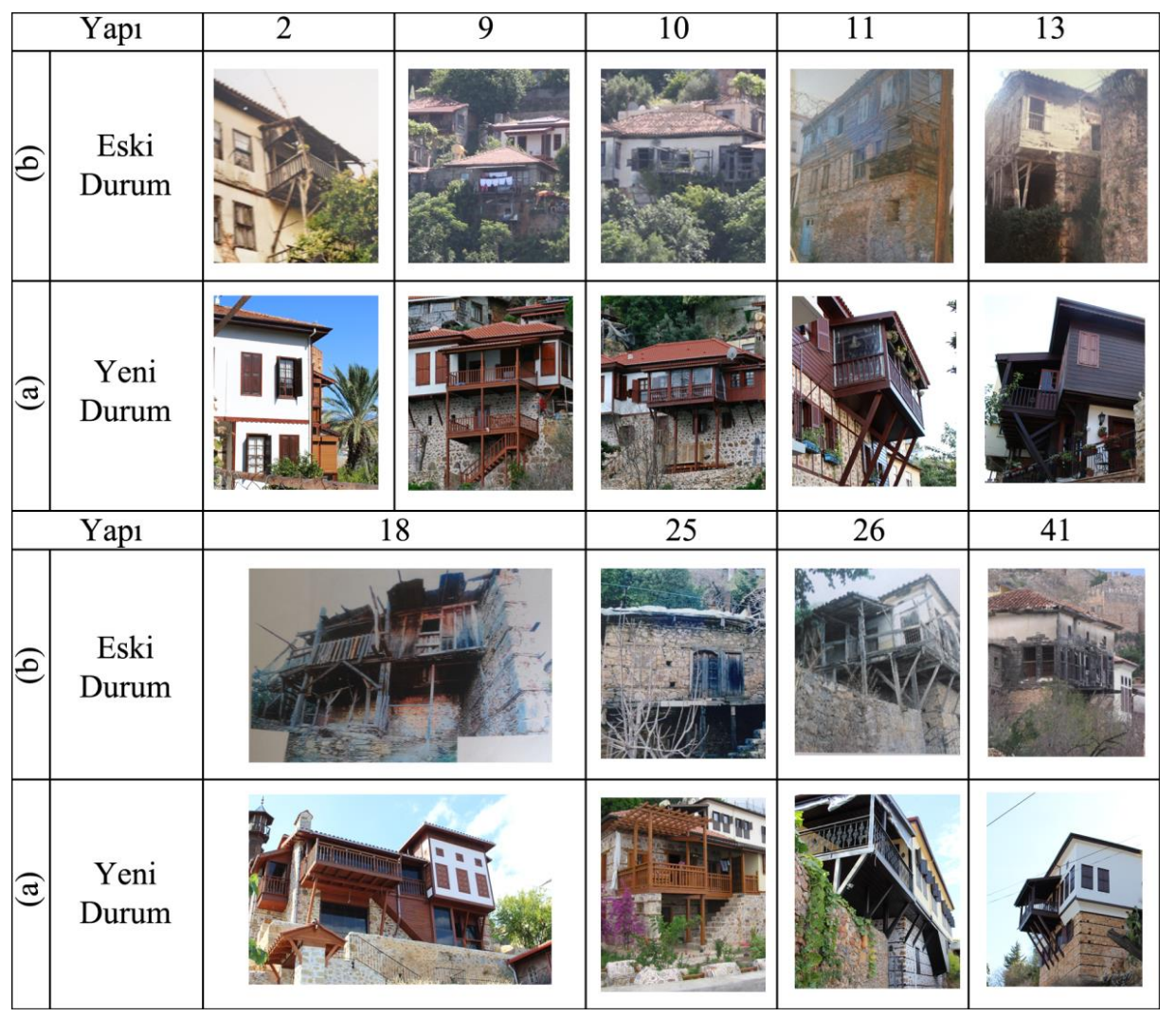

Manzaraya bakan çardaklar, yapıların en keyifli, en çok vakit geçirilen ve en önemli noktalarındadır. Bu nedenle yeni sahipleri için oldukça önem taşıyan çardağın ebatlarının büyütülmesi hatta varlığı tespit edilemeyen yapılarda dahi eklenme isteği, yapı sahipleri tarafından çokça dile getirilen istekler arasındadır. Alanya Kale silüetini oluşturan çardakların yer aldığı bu cepheler, kentin kimliği açısından oldukça önemlidir. Bu noktada restorasyon 
mimarının ve koruma kurullarının önceliği; mülk sahiplerinin kişisel istekleri değil yapının bilgibelge değerini korumak olmalıdır.

Tablo 7. Çardakların Alandaki Kullanım Durumu

\begin{tabular}{|c|c|c|c|c|}
\hline \multirow{2}{*}{} & \multicolumn{2}{|c|}{ Eski-Yeni Halinde Bulunan } & \multicolumn{2}{c|}{ Sadece Yeni Halinde Bulunan } \\
\cline { 2 - 5 } & Yapı No & Yapı Sayısı & Yapı No & Yapı Sayısı \\
\hline \multirow{2}{*}{ Fotoğrafına Ulaşılabilen Yapılar } & $\begin{array}{c}2-9-10-25 \\
26-35-41\end{array}$ & 7 & $11-13-18-37-46$ & Yapı Sayısı \\
\hline \multirow{2}{*}{ Dokunulmamış Yapılar } & \multicolumn{2}{|c|}{ Yapı No } & 15 \\
\hline
\end{tabular}

- Çatı Konstrüksiyonu / Çatı örtüsü

Alanda yer alan yapıların üst örtüleri, düz toprak dam veya alaturka kiremitli kırma çatılardan oluşmaktadır. Bazı yapılarda iki tip çatıda gözlenebilmektedir. Yapıların özgün kiremit döşemesinde, sağanak yağışlarda çatıda biriken suyun hemen tahliye edilebilmesi için altta kalan kiremitlerin üste döşenen kiremitlere göre daha yayvan olarak yerleştirildiği tespit edilmiştir.

Maalesef kiremit örtüsü olarak günümüzde tek tip ve en yaygın olan alaturka kiremit kullanılmaktadır. Kültür ve Tabiat Varlıklarını Koruma Kurulu'nda yer alan fotoğraflarda bazı yapılar da izine rastlanmamasına rağmen, çardak üst kısımları kapatılmıştır. Bahsedilen üst örtü eklemesi dışında incelenen 14 yapının \%50'sinde (2-11-13-25-41-46-48 nolu yapılar) eklemlenen çardak ile birlikte ahşap çatı konstrüksiyonları ile üst örtü de eklemlenmiştir. İncelenen 14 yapının \%7,14'ünde (41 nolu yapı) çatı konstrüksiyonu kaldırılıp yerine toprak dam yapıldığı tespit edilmiştir. İncelenen 14 yapının \%14,28'inde(2 yapı) hiçbir değiş̧iklik yapılmamıştır. İncelenen 14 yapının \%35,71'inde ise (2-9-18-26-37nolu yapılar)şekil, detay ve malzeme değişimleri gerçekleştirildiği tespit edilmiştir.

Yağmur sularının tahliyesi için döneminde uygulanan özgün çözüm metodları malzeme değişimi ile yok edilmektedir. Çatı konstrüksiyonları ile ilgili yaşanan bir diğer problem ise eklenen çardaklardan kaynaklı olanlardır. 


\subsubsection{Kaplama Elemanları / Cephe Kaplaması}

Birinci katlarda farklı iki yapım tekniğinin bir arada kullanıldığı evlere bölgede oldukça sık rastlanır. Bu yapılarda hayat ve hayata bağlı mekânların manzara yönünde yer alan bölümler ahşap karkas olarak yapılmışken, yamaca bakan arka kısımlarında zemin kattan gelen moloz taş duvar dokusuna devam edilmiştir. Bu ön cepheler ve yan cepheler bazı yapılarda özelleşerek sıvanmak yerine ahşap kaplamalı yapılmıştır (Tablo 9).

İncelenen 14 yapının \%50'sinde(7 yapı) cephe kaplaması bulunmaktadır. Bu 7 yapının \%57,14'ünde $(2,9,11,13$ nolu yapılar) kaplama malzemesinin yönü, boyutu değişmiştir. 7 yapının \%14,28'inde (18 nolu yapı) ise özgününde kaplama olmamasına rağmen kaplama eklenmiştir. 7 yapının \%28,57'sinde (25 ve 48 nolu yapılar) özgününde var olan kaplamalar kaldırımıştır (Tablo 9, 10).

Tablo 8. Restore Edilmiş Yapılarda Ahşap Cephe Kaplaması Durum Tespiti

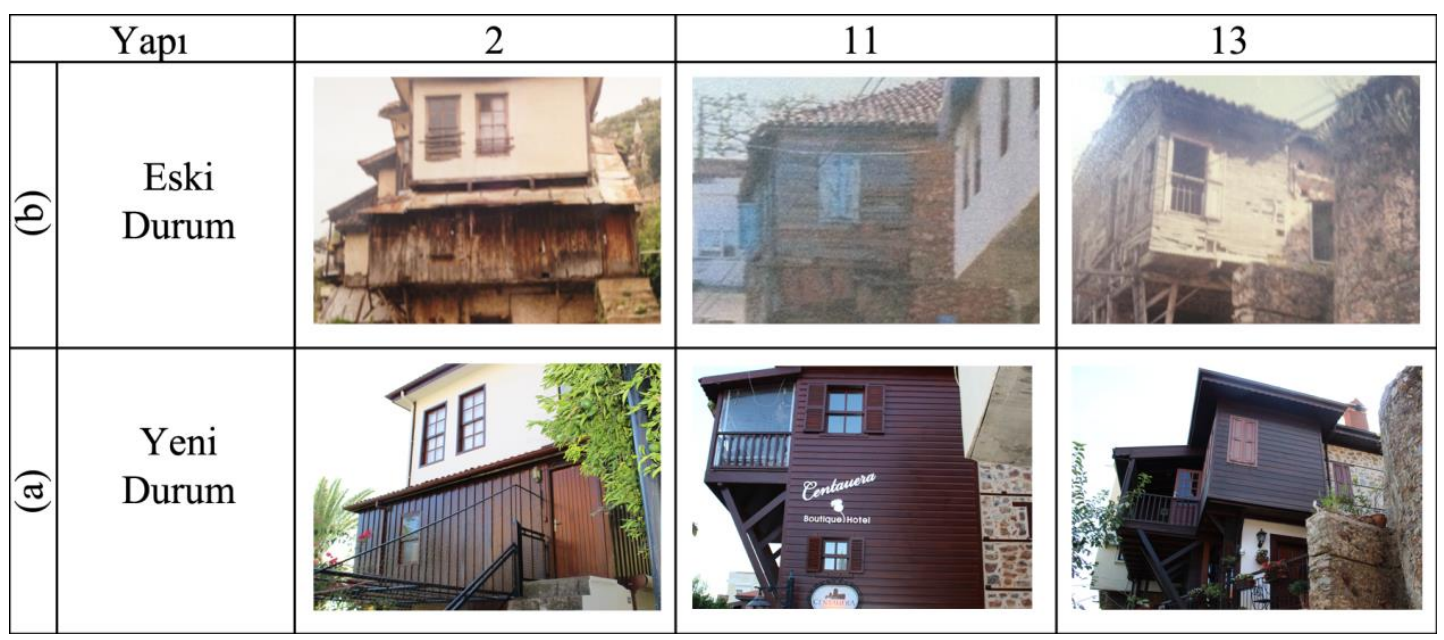

Tablo 9. Restore Edilmemiş Yapılarda Ahşap Cephe Kaplaması Durum Tespiti

\begin{tabular}{|c|c|c|c|c|c|}
\hline Yap1 & 6 & 8 & 14 & 19 & 53 \\
\hline Fotoğraf & & & & 14 \\
& & & & & \\
\hline
\end{tabular}


Kaplamalar yapıldığı dönemin gerekliliği dışında süslemeye dönüşmeye başlayıp özünü yansıtamamaktadır. Mevcut doku kimliğinden farklı ve pek de anlamlı olmayan çözümler üretildiği tespit edilmiştir.

\subsubsection{Ahşap Doğrama Elemanları}

- $\quad$ Giriş Kapısı

Bölgede yer alan yapıların giriş kapıları genellikle iki kanatlı ve ahşap olup zemin katta yer alan gedey ${ }^{8}$ adı verilen alana açılmaktadır.

Arazinin eğimli olması bazı yapıların denize bakan cephelerine ulaşmamıza engel olmuştur. Bu nedenle 5 yapının $(12,18,25,35$ ve 48 nolu yapılar) giriş kapılarına ulaşılamamıştır.

İncelenen 14 yapıdan giriş kapısına ulaşılan \%11,11'inin(26 nolu yapı) kapısında herhangi bir değişim görülmemektedir. 9 yapının \%11,11'ine (41 nolu yapı) kapı eklendiği görülmektedir. 9 yapının \%77,77'sinde(7 yapı) ise şekil, boyut, yer, malzeme değişimi tespit edilmiştir.

Bu ekleme ve değişimlerin nedenleri büyük oranda günümüz konfor şartları olsa da bu tarz müdahalelerden mümkün olduğunca kaçınılması ve yapının özünün korunması gerekmektedir.

- $\quad$ Ahşap Pencere

Manzara yönüne kurgulanmış olan çağnişir ${ }^{9}$ mekanı; ahşap söveli, dört ayrı ahşap kapağı ve yöreye özgü demir parmaklıkları olan büyük pencereleri ile göze çarpar, bazı yapılarda manzara boyunca devam eden bu pencerelerin üzerinde daha küçük boyutta pencereler yer alır. Restore edilmemiş yapılarda pencere-kepenk ilişkisi çok net okunmaktadır. Evlerin moloz taş olan zemin kat cephelerindeki pencerelerin ahşap kapakları ve demir parmaklıkları vardır. Ancak iklimsel şartlardan ve eğimden dolayı bu cephede pencereye pek rastlanmaz (Tablo11).

\footnotetext{
${ }^{8}$ Evin altında bulunan ahır ve samanlık mekanı (Hacıkura, 2000:224).

${ }^{9}$ Alanya evlerinde başodaya verilen isim (Hacıkura, 2000:224).
} 
Tablo 10. Restore Edilmemiş Yapılarda Pencere-Kepenk Durum Tespiti

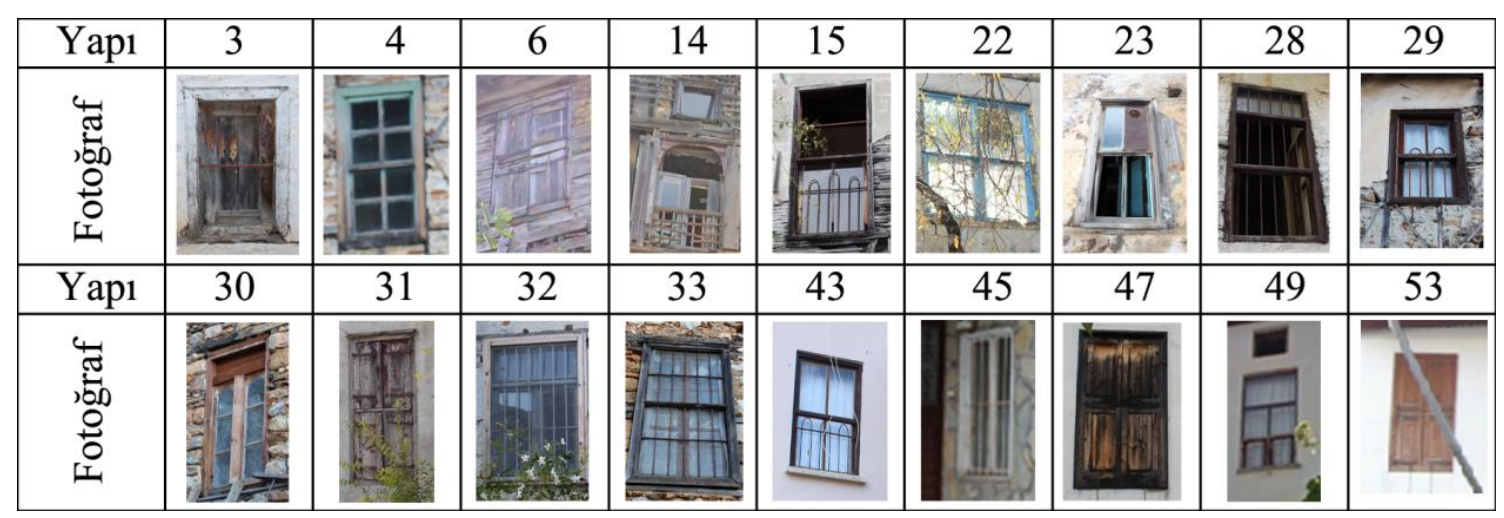

Yapılan çalışmada zemin kat cephesinde yeni yaşam standartları gereği açılmış olan pencereler görülmektedir. İncelenen 14 yapının \%57,14'ünde (9-11-12-13-18-25-37-41 nolu yapılar) yeni açılan pencereler görülmektedir. 14 yapının \%50'sinin (2-9-11-12-18-26-46 nolu yapılar) pencerelerinde şekil, boyut, malzeme ve detay değişimleri ve 14 yapının \%7,14'ünde ise (2 nolu yapı) kaldırılmış pencere tespit edilmiştir (Tablo 12).

Bu ekleme ve değişimlerin büyük oranda nedenleri günümüz konfor şartları olsa da bu tarz müdahalelerden mümkün olduğunca kaçınılması ve özünün korunması gerekmektedir. Kaçınılmadığı taktirde de en uygun malzeme ve detay çözümleri ile gerekli müdahaleler yapılmalıdır. 
Tablo 11. Restore Edilmiş Yapılarda Pencere-Kepenk Durum Tespiti

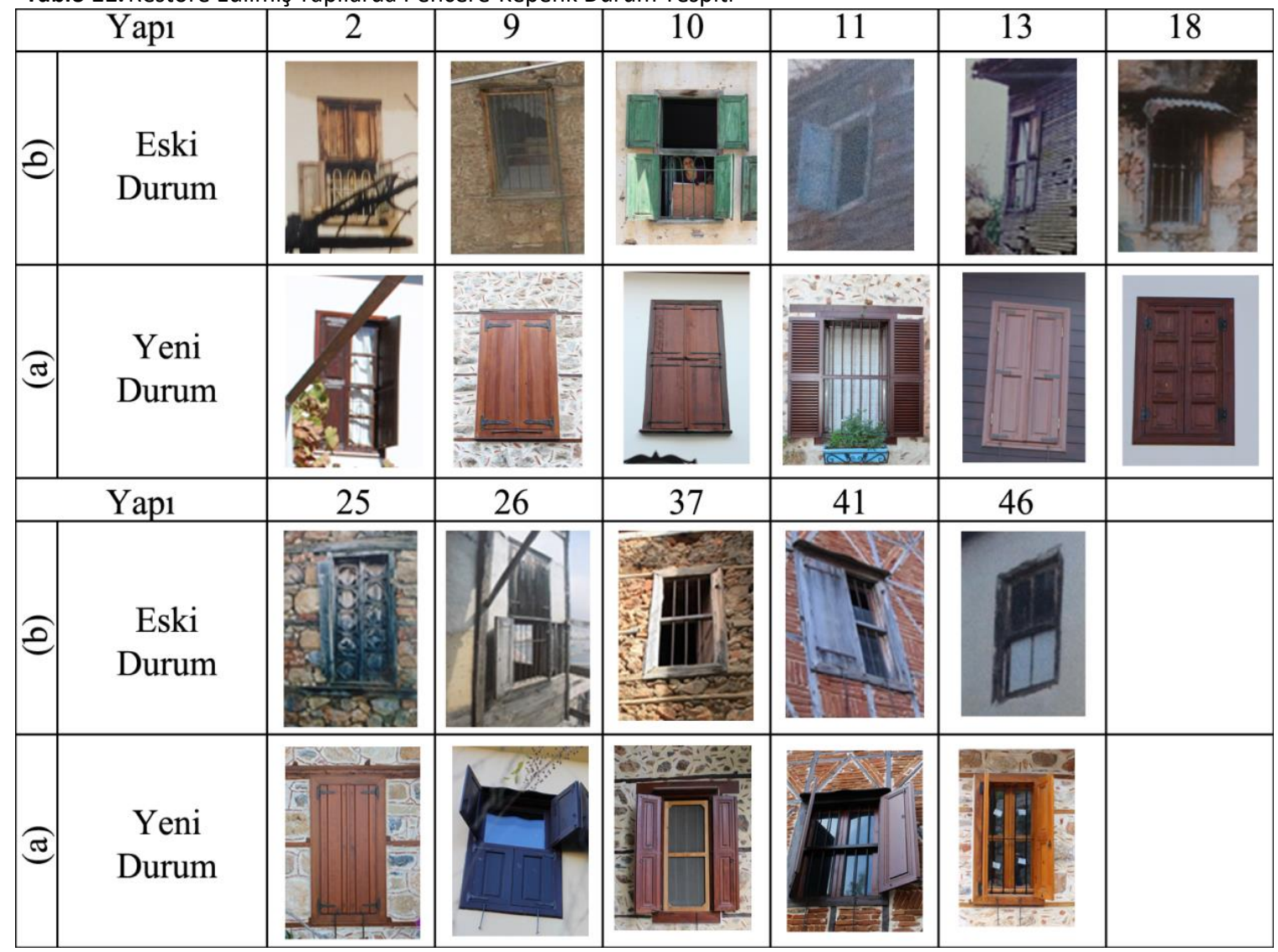

- $\quad$ Ahşap Kepenk / Kapak

Bölgede gibi yapılarda 4 kapaklı kepenk kullanılırken kimi yapılarda 2 kapaklı kepenkler kullanılmaktadır. İncelenen 14 yapıdan \%14,28'i 2 yapıda (2 ve 46 nolu yapılar) var olan kapakların kaldırıldığı, 14 yapının \%42,85'i 6 yapıda $(9,11,12,13,18,25,37$ ve 41 nolu yapılar) kapak eklendiği ve 14 yapının \%57,14'ü 8 yapıda $(2,10,11,12,13,25,35$ ve 41 nolu yapılar) şekil, boyut, detay ve malzeme değişimleri tespit edilmiştir. Şekil ve detay değişimi olan yapılarda özgün motifler değiştirilmiştir.

Elimizdeki veri yetersizliğinden, fotoğrafların eski ve kalitesinin düşük olmasından, kırılmış da olsa kapakların var olup olmadığı tespit edilememiştir (Tablo 11).

Kepenklerde yapılan bu değişimler bölge tipolojisini olumsuz yönde etkileyip bilgibelgenin değişmesine neden olmaktadır. Bu nedenle restorasyon projesinde gerekli araştırmaincelemeler detaylı bir şekilde yapılarak en uygun müdahale kararı alınmalıdır. 


\section{Araştırma Sonuçları}

Çalışma kapsamında incelenen Alanya Tophane mahallesinde yer alan restorasyon geçirmiş 14 yapının cephelerinde restorasyon kaynaklı değişimler ve farklılıklar tespit edilmiştir. Restorasyon geçirmemiş, özünü koruyan yapılarda alana ait yapı elemanlarının durumu tespit edilip, eski-yeni fotoğraf karşılaşması yapıldığında;

- 14 yapıdan 11 'inde kullanılan taş duvar örgüsünde, taş çeşidinde ve boyutlarında değişimler olduğu,

- 14 yapıdan $10^{\prime}$ una çivileme tuğla örgüsü olmadığı halde ekleme yapıldığı,

- 14 yapının 10'unda harç malzemede değişim gözlendiği, 4'ünde harç eklemesi yapıldığı,

- 14 yapıdan 7'sinde dış merdiven bulunurken bu 7 merdivenden 1'ine merdiven eklendiği, 1'inden de merdiven kaldırıldığı, 5'inde de çeşitli değişimler olduğu,

- 14 yapıdan 8'inde dikme bulunurken bu 8 yapıdan 4'üne ek dikmeler yapıldığı, 2'sinde kaldırıldığı,

- 14 yapıdan 12 'sinde payanda bulunurken bu 12 yapıdan 7'sinde yeni payandalar eklendiği, 2'sinden payanda kaldırıldığı, 2'sinde de çeşitli değişimler olduğu,

- 14 yapıdan 13'ünde hatıl ve lento görülmektedir. Bu 13 yapıdan 2'sinde kaldırıldığı, 3'ünde eklemeler yapıldığı, 4'ünde çeşitli değişimlerin olduğu,

- Arazi koşullarından dolayı çardağına ulaşılabilen 12 yapıdan 5'ine çardak eklendiği, 5'inde çeşitli değişimlerin olduğu ve çardaklara çeşitli üst örtüler eklendiği,

- 14 yapıdan 7'sinde cephe kaplaması bulunurken bu 7 yapıdan 4'ünde çeşitli değişimlerin olduğu, 2'sinde kaplamanın kaldııldığı, 1'inede kaplama eklendiği,

- Arazi koşullarından dolayı giriş kapısına ulaşılabilen 9 yapıdan 1'ine kapı eklendiği, 7'sinde çeşitli değiş̧imler olduğu,

- 14 yapıdan 8'ine yeni pencereler açıldığı, 7'sinde çeşitli değişimler olduğu, 1'inde ise bazı pencerelerin iptal edildiği,

- 14 yapıdan 2'sinde var olan pencere kapaklarının kaldırıldığı, 6'sına pencere kapağı eklendiği, 8'inde çeşitli değişimler olduğu, tespit edilmiştir (Tablo 13). 
SDÜ ART-E

Güzel Sanatlar Fakültesi Sanat Dergisi

Aralık'17 Cilt: 10 Sayı: 20

ISSN 1308-2698

Tablo 12. Alanda meydana gelen değişimlerin yapılara göre durumları

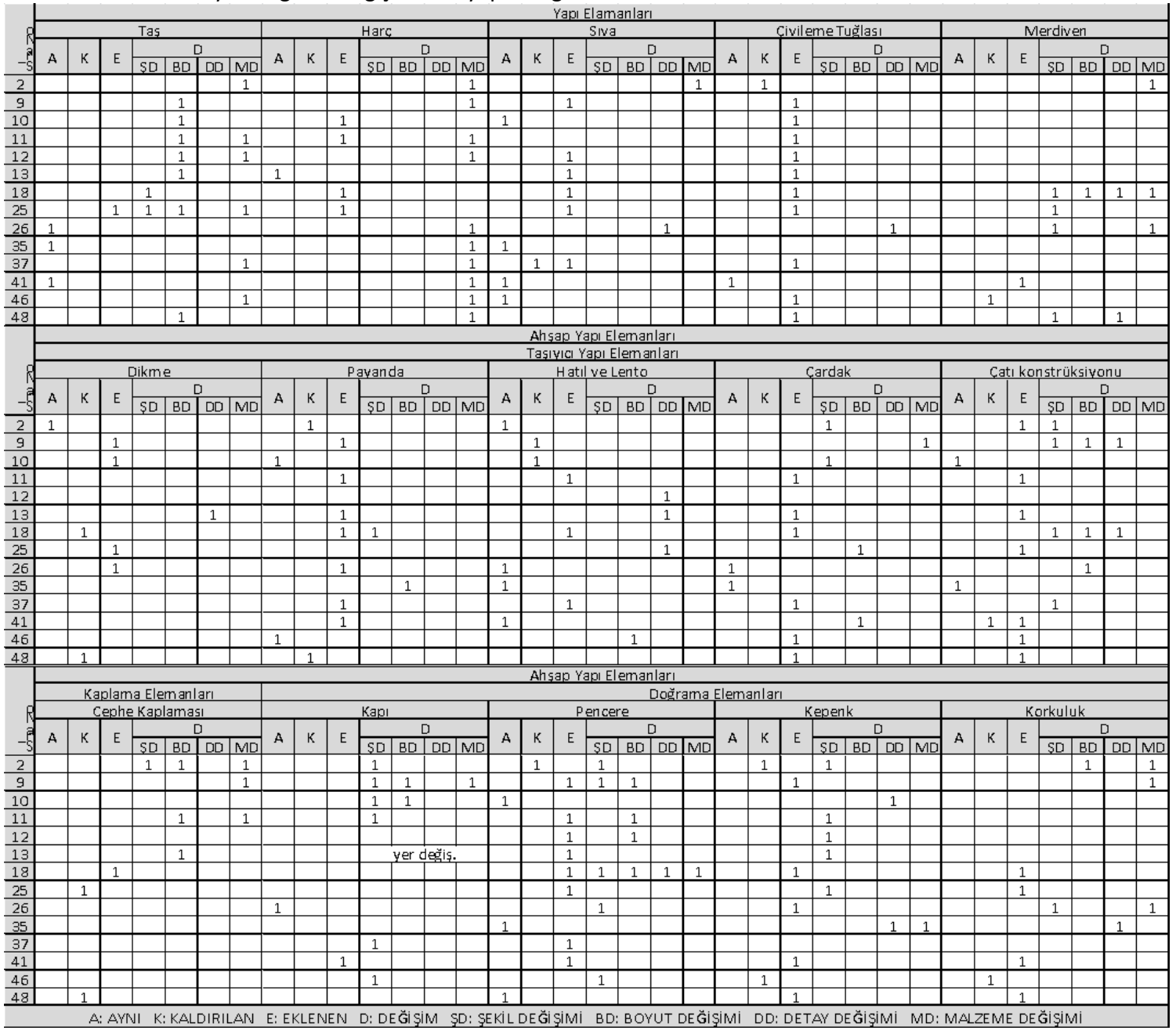

\section{Sonuç ve Öneriler}

Çağımızın getirdiği yenilikler ile birlikte yaşam tarzı ve standartları da değişmiştir. Bu değişiklikler ile birlikte kültür varlıklarımız, hem terk edilme tehlikesi ile hem de yeni hayatla birlikte gelen yeni işlev ve modern yaşama uyarlama için yapılan restorasyon tehlikesi ile karşı karşıya kalmaktadır.

Restorasyon, geleneksel konutlarda yaşamın devamlılığını ve konforunu sağlamak için kaçınılmaz bir müdahale şekli olabilir. Ancak, bu müdahalenin dozajı ve şekli son derece önemlidir. Restorasyon uygulaması, yapının özgün niteliklerini değiştirerek, özgün malzeme ve yerel iş̧̧ilik kullanılmadan yapıldığı zaman, büyük sorunlarla yüzleşilmesi aşikârdır. 
Koruma kavramının temel amacının yapıların özgünlüğünü ve bütünlüğünü korumak olduğu ayrıca mevcut malzemenin olabildiğince yerinde muhafaza edilerek koruma işleminin gerçekleşmesi gerektiği yasalar ve tüzüklerde de detaylı olarak belirtilmiştir. Yapılacak koruma müdahaleleri mevcut şartlara göre tarihi değerlere ve yapının bütünlüğüne saygı duyularak yapılmalıdır.

Kültürel mirasın özgününün korunarak, geçmişe ait bilgi ve belgenin gelecek nesillere ulaşmasının sağlanabilmesinde kullanılan 'restorasyon' eyleminin doğru yaklaşımlarla gelecekte yanılgıya düşürmeyecek şekilde yapılması gereken bilimsel bir çalışma (Asatekin, 1995: 68) olması gerekirken yapılan incelemeler sonucunda, çalışma alanındaki yapıların öz kimliklerini büyük oranda kaybettiği tespit edilmiştir (Tablo 14 ). Ama kaynak yetersizliğinden dolayı hangi aşamada bu sorunun ortaya çıktığı tespit edilememiştir.

Tablo 14. Bölgede tespit edilen sorunlar ve çözüm önerileri

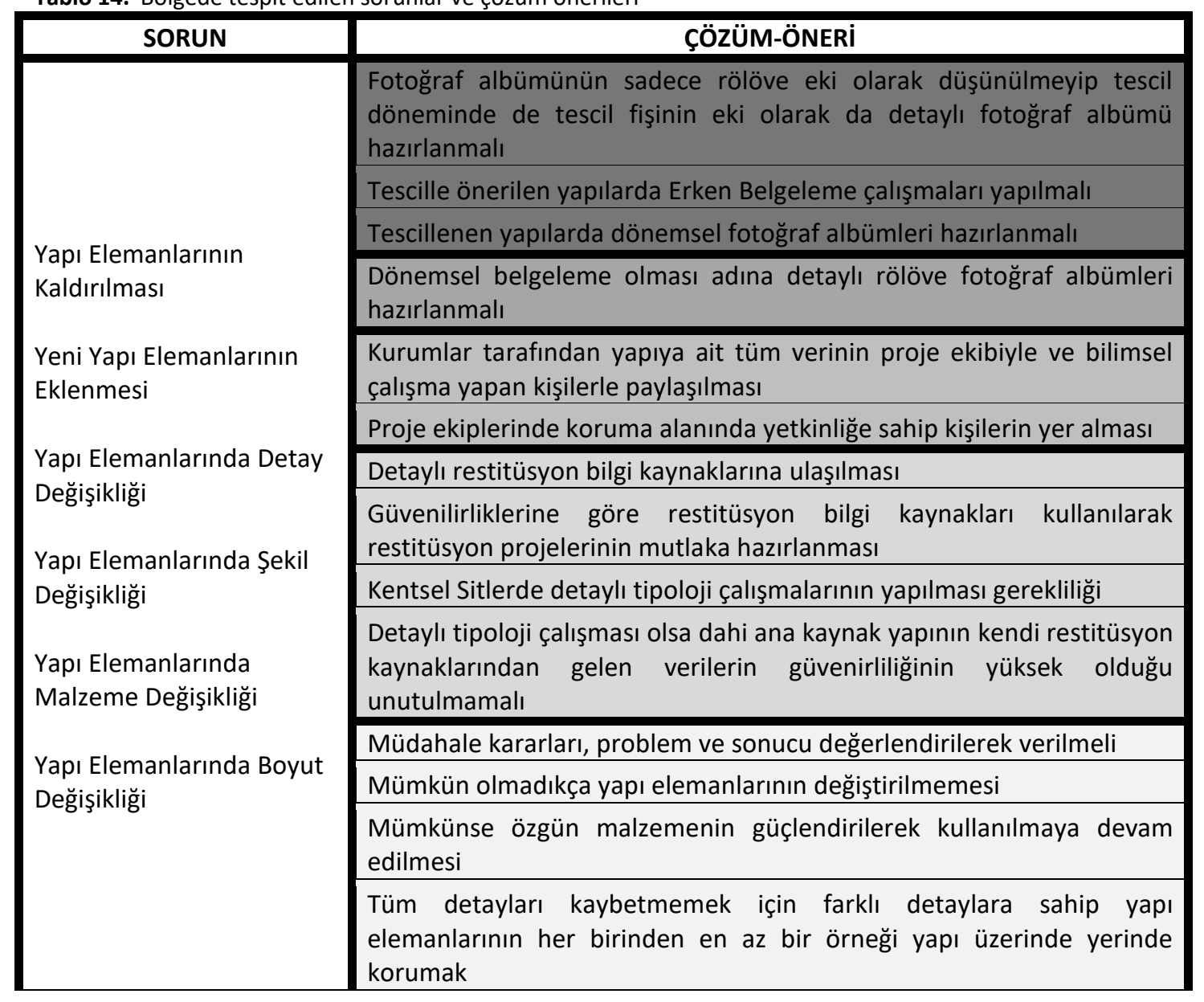




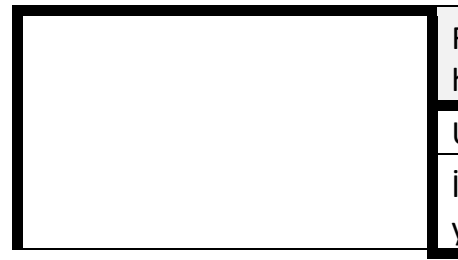

Farklı detaylara sahip yapı elemanlarını eğer yerinde koruyamıyorsak her birinden en az bir örneği yapı üzerinde sergilenmeye devam etmek

Uygulama ekibinde kalifiye elemanların yer alması

İlgili kurum ve kuruluşlar tarafından gerekli detaylı denetlemenin yapılması

Tarihi yapılar tescile önerilirken 2-3 noktadan çekilen fotoğraflarla tescil fişi oluşturmak yerine önerilen eserlere tescil fişinin eki olarak detaylı fotoğraf albümü hazırlanması daha uygun olacaktır. Hazırlanan fotoğraf albümleri erken belgeleme adına son derece önemlidir. Ayrıca dönemsel olarak yapıya ait yeni fotoğraf albümlerinin oluşturulması, yapının tarihsel sürecini anlatması ve bir sonraki çalışmalara doğru yol gösterebilmesi adına önemlidir (bkz. Tablo 14).

Restorasyon çalışması yapılacak olan yapı için dönemsel belgelemeyi doğru sunabilmek adına rölöve eki olarak yapılan fotoğraf albümleri yapının bütün detaylarını sistematik anlatacak şekilde kurgulanmalıdır (Tablo 14).

İlgili kurum ve kuruluşlar tarafından yapıya ait tüm verinin bilimsel çalışma yapan kişilerle paylaşılması yeni bilgi kaynaklarının oluşabilmesi adına oldukça önemlidir. Ayrıca tüm verilerin proje ekibiyle paylaşılması doğru restitüsyon kararlarının ortaya çıkabilmesi adına oldukça önemlidir. Bu paylaşımlar sayesinde doğru müdahale kararları üretilebilecektir. Üretilen müdahale kararının doğru yapılabilmesi adına sürecin doğru yürütülmesi oldukça önemlidir. Bu nedenle lisans eğitiminde koruma dersleri yeterli düzeyde olmadığından dolayı proje ekiplerinde koruma alanında yüksek lisans eğitimini almış yetkin kişilerin yer alması oldukça önemlidir (Tablo 14).

Bilgiye erişilebilirliğin önemi unutulmayarak, restitüsyon bilgi kaynaklarının rölöverestitüsyon-restorasyon projelerini hazırlayacak ekiple ve bilimsel çalışma yapacak kişilerle paylaşılması oldukça önemlidir. Restorasyon yapılacak yapıyla ilgili tüm bilgi kaynaklarına ulaşılması ve hakim olunması gerekmektedir. Bölgede rastlanan restorasyon sorunlarının çoğunluğu zamanında doğru belgelemenin yapılamamış olması ve veri kayıplarının yaşanmasından kaynaklanmaktadır. Bu nedenle belgeleme çalışmasında, restitüsyon çalışmaları yüzeysel değil detaylı bilgi kaynakları kullanımı ve güvenirliğine göre sınıflandırılarak 
kullanılmasıyla oluşturulmalıdır. Kentsel tipolojinin oluşturulması adına yapılan çalışmaların önemi yadsınamamakla birlikte güvenilirlik açısından yapının kendisinden gelen veriler çok daha önemlidir. Bu nedenle öncelik yapıdan gelen veriler olmalıdır (Tablo 14).

Restorasyon müdahale kararları alınırken problem ve sonucu değerlendirilerek verilmesi gerekmektedir. Bu aşamada restitüsyona bağlı olarak kararlar oluşturulmalıdır. Bunun yanında analiz paftası da restorasyonun en büyük kaynaklarından biridir. Müdahale kararları üretilirken mümkün olduğunca yapının özgün elemanları değiştirilmeden güçlendirilerek korunmalıdır. Tüm detayları kaybetmemek için farklı detaylara sahip yapı elemanlarının her birinden en az bir örneği yapı üzerinde yerinde korumalıyız. Eğer bu detayları yerinde, işleviyle koruyamıyorsak en az bir örneği yapı üzerinde sergilemeye devam etmemiz gerekmektedir (Tablo 14).

Uygulamalar yapılırken proje ekibinin yetkin olmasının yanında uygulama ekibi de kalifiye elemanlardan oluşması gerekmektedir ki ortak çalışmayla doğru müdahaleler yapılabilsin. Tüm bunlar yapılırken ilgili kurum ve kuruluşlar tarafından da gerekli detaylı denetleme yapılarak yanlış müdahalelerin önüne geçilerek doğru bilgi ve belge gelecek nesillere aktarılabilir (Tablo 14).

Tüm bunların yanında bilgi eksiklikleri, imalat niteliğindeki zafiyetler ve mülk sahibiimalatçı arasındaki zihinsel gel-gitler, tarihi yapıdaki tahribatın derinliğini arttırmaktadır. Gerçekle ilgisi olmayan eklentiler yüzünden, sözde tarihi yapıyı 'cicileştirme', 'evcilleştirme', 'ehlileştirme' çabaları hızla devam etmektedir. Sanki tarihi yapı, yapıldığı zaman diliminde iyi tasarlanamamış da, günümüzde onu yeniden elden geçirmek gerekirmiş gibi davranmak, kültürel mirası koruma bilincinin ruhuna son derece aykırı bir tutumdur. Restorasyon yapılmasını meşrulaştırma ve yaygınlaştırma gayretleri bu tür ilkel anlayışlar sonucunda inanırlığını kaybetmeye başlamıştır. Tarihi yapıların 'öz'ünü bozan, 'aslı'nı inkâr noktasına getiren uygulamalar sayesinde bilimsellikten uzak, tarihsel sürekliliğe faydasız, dürüst olmayan ürünler ortaya çıkmaktadır. Ancak özelliğini henüz kaybetmemiş kurtarılmayı bekleyen yapılar için mevcut durumun hızlıca belgelenip değişmeden onarılmasının bölge kimliği açısından önemli bir adım olacağı unutulmamalıdır. Ayrıca malzemelerdeki değişim-dönüşümleri tespit etme amaçlı bu tarz çalışmaların diğer tarihi bölgeler için de yapılması varolan restorasyon 


\section{SDÜ ART-E}

Güzel Sanatlar Fakültesi Sanat Dergisi

sorunlarını kamuoyuna duyurulup, duyarlılık yaratılmasını sağlayarak bu tarz restorasyon sorunlarının oluşmasına engel olunabileceği öngörülmektedir.

\section{Kaynakça}

Asatekin, G. (1995). "Restorasyon Teriminin Yüklendiği Yeni Anlam”, Mimarlık Dergisi, Mimarlar Odası Yayınları, Sayı 261, s. 66-69

Barışta, H. Ö. (1996a). "Alanya'da Bazı Evlerde Görülen Taş İşçiliği", Alanya Tarih ve Kültür Seminerleri, s. 161-168

Barışta, H. Ö. (1996b). "Alanya Evlerinde Görülen Ağaç İşciliği Üzerine”, Alanya Tarih ve Kültür Seminerleri, s. 393-398

Bilici, Z. K. (2004). "Alanya Kalesi'nin Korunması Sorunu", 3. Alanya Tarih ve Kültür Seminerleri, 12-13 Aralık, s. 51-52

Bilici, Z. K. (2010). “Alanya-Tophane Mahallesi Konutlarındaki Onarımlar Üzerine: QuoVadis?”, XII. Ortaçağ-Türk Dönemi Kazıları ve Sanat Tarihi Sempozyumu, s. 149-153

Böke H. vd. (2004). "Tarihi Yapılarda Kullanılan Horasan Harcı ve Sıvalarının Özellikleri" Yapı Dergisi, Sayı: 269, s.90-95

Ceylan, O. (1997). "Geleneksel Alanya Evleri”, Art Decor, Sayı 57, s. 76-87

Çavuş, M. (2011). Tarihi Yapılarda Üst Örtülerin Çelik Malzeme Ille Sağlamlaştırılmasının Sonlu Elemanlar Yöntemiyle Modellenmesi, Yayımlanmamış Doktora Tezi, Ankara: Gazi Üniversitesi, Fen Bilimleri Enstitüsü, İnşaat Mühendisliği Ana Bilim Dalı.

Hacıkura, N. (2000). Alanya'da Müftüoğlu Evi Restorasyon Projesi, Yayımlanmamış Yüksek Lisans Tezi, İstanbul: İstanbul Teknik Üniversitesi, Fen Bilimleri Enstitüsü, Mimarlık Anabilim Dalı.

Kapancı, M. (2008). Alanya Kaleiçi Evleri, Yayımlanmamış Yüksek Lisans Tezi, Konya: Selçuk Üniversitesi, Fen Bilimleri Enstitüsü, Mimarlık Anabilim Dalı.

Küçükkaya, A. G. (2004). Taşların Bozulma Nedenleri ve Koruma Yöntemleri, İstanbul: Birsen Yayınevi.

Mahrabel, H. A. (2006). Tarihi Yapılarda Taşıyıcı Sistem Özellikleri, Hasarlar, Onarım ve Güçlendirme Teknikleri, Yayımlanmamış Doktora Tezi, İstanbul: İstanbul Teknik Üniversitesi, Fen Bilimleri Enstitüsü, İnşaat Mühendisliği Anabilim Dalı.

Pekmezci I. P. (2012), Çukurova Bölgesindeki (Kilikya) Bazı Tarihi Yapılarda Kullanılan Harçların Karakterizasyonu ve Onarım Harçları için Öneriler, Yayımlanmamış Doktora Tezi, İstanbul: İstanbul Teknik Üniversitesi, Fen Bilimleri Enstitüsü, Mimarlık Anabilim Dalı.

Şener, H. (1984). Alanya'da Geleneksel Konutlar, 1. Baskı, İstanbul: İstanbul Teknik Üniversitesi Baskı Atölyesi. 
Zakar, L. (2013). Retorasyon Uygulamalarında Kullanılan Çağdaş Teknikler, Yüksek Lisans Tezi, İstanbul: İstanbul Teknik Üniversitesi, Fen Bilimleri Enstitüsü, Mimarlık Anabilim Dalı.

\section{İnternet Kaynağı}

Tanyeli, U. (2005). “Restorasyon mu, Tahribat mı?”, Radikal, iki Pazar Gazetesi, 12 Haziran, s. 1. http://www.radikal.com.tr/radikal2/restorasyon-mu-tahribat-mi-872678/ Erişim Tarihi: 04.01.2017.

\section{Görsel Kaynaklar}

Görsel 1. Google Earth'den elde edilen veriler İpek DEMiR tarafından düzenlenmiştir. Tophane Silüeti fotoğrafı: http://www.alanya.tv/tr/AlanyaTarihiYerler/Tersane/, Erişim tarihi:

23.11.2017

Görsel 2. Tüm fotoğraflar Hicran Hanım HALAÇ ve İpek DEMIR Kişisel Arşivlerinden

Görsel 3. Alanya Belediyesi'nden alınan halihazır haritası üzerinden yapılan mevcut durum analizlerinden Hicran Hanım HALAÇ ve İpek DEMIR tarafından oluşturulmuştur.

Görsel 4. Hicran Hanım HALAÇ ve İpek DEMIR tarafından yapılmıştır.

Tablo 2. Alanya Belediyesi Koruma Uygulama ve Denetleme Bürosundan elde edilen veriler derlenerek Hicran Hanım HALAÇ ve İpek DEMIR tarafından tablolaştırılmıştır.

Tablo 3. 50 nolu fotoğraf: Alanya Belediyesi Kent Bilgi Sistemi, http://kbs.alanya.bel.tr/\#, Erişim tarihi: 04.01.2017

Tablo 4. 3-4-6-14-15-20-21-22-23-24-27-28-29-30-31-32-33-43-45-47-50 nolu fotoğraflar: Hicran Hanım HALAÇ ve İpek DEMIR Kişisel Arşivlerinden

Tablo 6. Eski durumlar (b grubu): Antalya Kültür Varlıklarını Koruma Bölge Kurulu Arşivi

Tablo 6. Yeni durumlar (a grubu): Hicran Hanım HALAÇ ve İpek DEMiR Kişisel Arşivlerinden

Tablo 7. Eski durumlar (b grubu): Antalya Kültür Varlıklarını Koruma Bölge Kurulu Arşivi

Tablo 7. Yeni durumlar (a grubu): Hicran Hanım HALAÇ ve İpek DEMiR Kişisel Arşivlerinden

Tablo 9. Eski durumlar (b grubu): Antalya Kültür Varlıklarını Koruma Bölge Kurulu Arşivi

Tablo 9. Yeni durumlar (a grubu): Hicran Hanım HALAÇ ve İpek DEMIR Kişisel Arşivlerinden

Tablo 10. 53 nolu fotoğraf: Alanya Belediyesi Kent Bilgi Sistemi, http://kbs.alanya.bel.tr/\#, Erişim tarihi: 04.01.2017

Tablo 10. 6-8-14-19 nolu fotoğraflar: Hicran Hanım HALAÇ ve İpek DEMiR Kişisel Arşivlerinden

Tablo 11. 49-53 nolu fotoğraflar: Alanya Belediyesi Kent Bilgi Sistemi, http://kbs.alanya.bel.tr/\#, Erişim tarihi: 04.01.2017 
Tablo 11, 3-4-6-14-15-22-23-28-29-30-31-32-33-43-45-47 nolu fotoğraflar: Hicran Hanım HALAÇ ve İpek DEMiR Kişisel Arşivlerinden

Tablo 12, Eski durumlar (b grubu): Antalya Kültür Varlıklarını Koruma Bölge Kurulu Arşivi

Tablo 12, Yeni durumlar (a grubu): Hicran Hanım HALAÇ ve İpek DEMIR Kişisel Arşivlerinden

Tablo 13, Çalışmadan elde edilen veriler Hicran Hanım HALAÇ ve İpek DEMiR tarafından tablolaştırılmıştır.

Tablo 14, Çalışmadan elde edilen veriler Hicran Hanım HALAÇ ve İpek DEMiR tarafından tablolaştırılmıştır. 